Article

\title{
Pressure-Temperature History of the $>3$ Ga Tartoq Greenstone Belt in Southwest Greenland and Its Implications for Archaean Tectonics
}

\author{
Vincent van Hinsberg ${ }^{1, *}$, Catherine Crotty ${ }^{1}$, Stan Roozen ${ }^{1}{ }^{(\mathbb{C}}$, Kristoffer Szilas ${ }^{2}{ }^{(D)}$ and \\ Alexander Kisters ${ }^{3}$ \\ 1 Department of Earth and Planetary Sciences, McGill University, Montreal, QC H3A 0E8, Canada; \\ catherine.crotty@mail.mcgill.ca (C.C.); stan.roozen@mail.mcgill.ca (S.R.) \\ 2 Department of Natural Resource Management, University of Copenhagen, 1350 Copenhagen, Denmark; \\ krsz@ign.ku.dk \\ 3 Department of Earth Sciences, Stellenbosch University, 7602 Stellenbosch, South Africa; akisters@sun.ac.za \\ * Correspondence: V.J.vanHinsberg@gmx.net; Tel.: +1-514-398-6767
}

Received: 31 July 2018; Accepted: 28 September 2018; Published: 30 September 2018

check for updates

\begin{abstract}
The Tartoq greenstone belt of southwest Greenland represents a well-preserved section through $>3$ Ga old oceanic crust and has the potential to provide important constraints on the composition and geodynamics of the Archaean crust. Based on a detailed structural examination, it has been proposed that the belt records an early style of horizontal convergent plate tectonics where elevated temperatures, compared to the modern-day, led to repeated aborted subduction and tonalite-trondhjemite-granodiorite (TTG) type melt formation. This interpretation hinges on pressure-temperature $(\mathrm{P}-\mathrm{T})$ constraints for the belt, for which only preliminary estimates are currently available. Here, we present a detailed study of the pressure-temperature conditions and metamorphic histories for rocks from all fragments of the Tartoq belt using pseudosection modelling and geothermobarometry. We show that peak conditions are predominantly amphibolite facies, but range from 450 to $800{ }^{\circ} \mathrm{C}$ at up to $7.5 \mathrm{kbar}$; reaching anatexis with formation of TTG-type partial melts in the Bikuben segment. Emplacement of the Tartoq segments into the host TTG gneisses took place at approximately $3 \mathrm{Ga}$ at $450-500{ }^{\circ} \mathrm{C}$ and $4 \mathrm{kbar}$ as constrained from actinolite-chlorite-epidote-titanite-quartz parageneses, and was followed by extensive hydrothermal retrogression related to formation of shear zone-hosted gold mineralisation. Tourmaline thermometry and retrograde assemblages in mafic and ultramafic lithologies constrain this event to $380 \pm 50{ }^{\circ} \mathrm{C}$ at a pressure below 1 kbar. Our results show that the convergent tectonics recorded by the Tartoq belt took place at a P-T gradient markedly shallower than that of modern-day subduction, resulting in a hot, weak and buoyant slab unable to generate and transfer 'slab pull', nor sustain a single continuous downgoing slab. The Tartoq belt suggests that convergence was instead accomplished by under-stacking of slabs from repeated aborted subduction. The shallow P-T path combined with thermal relaxation following subduction stalling subsequently resulted in partial melting and formation of TTG melts.
\end{abstract}

Keywords: Tartoq greenstone belt; metamorphic history; Archaean; Greenland; plate tectonics

\section{Introduction}

The Tartoq greenstone belt consists of a number of km-sized mafic crustal blocks enclosed by orthogneisses of tonalite-trondhjemite-granodiorite (TTG) affinity on either side of the Sermilligaarsuk fjord in southwest Greenland (Figure 1) [1,2]. The Tartoq belt is part of the North Atlantic craton and is located on its southern margin [3]. A Palaeoproterozoic (Ketilidian-age) basin overlays the Tartoq 
belt in the east [4]. The main blocks are, from west to east, Nuuluk, Iterlak, Amitsuarsua, Bikuben, Akuliaruseq, Naalagaaffik, and Nuna Qaqortoq (in earlier works, these blocks are also referred to as Nuluk, Iterdlak, Midternæs North, Sioralik, Midternæs West, Midternæs East, and Nuna Qaqertoq, respectively). The blocks represent a disaggregated greenstone belt and expose different crustal levels of this original belt. The various blocks cannot be reassembled and thrusting and folding of the lithologies means that the stratigraphy of the belt is repeated within the blocks, and likely among them (see also [1]). Boundaries with the enclosing TTG orthogneisses are either tectonic (e.g., thrust contacts in Nuuluk and Iterlak) or intrusive (e.g., an intrusive breccia forming the northern boundary on Amitsuarsua and a progressive increase in TTG melt sheets in the southwest of Bikuben). The age of the belt is constrained from cross-cutting felsic melts to be more than $2.9 \mathrm{Ga}$ [5,6], with Lu-Hf whole rock dating of the mafic lithologies giving an errorchron age of approximately 3.2 Ga [6]. Felsic lithologies provide zircon $\mathrm{U}-\mathrm{Pb}$ ages clustering around 3.0 Ga [7], but these may represent the age of the enclosing TTGs (see below and [2]).

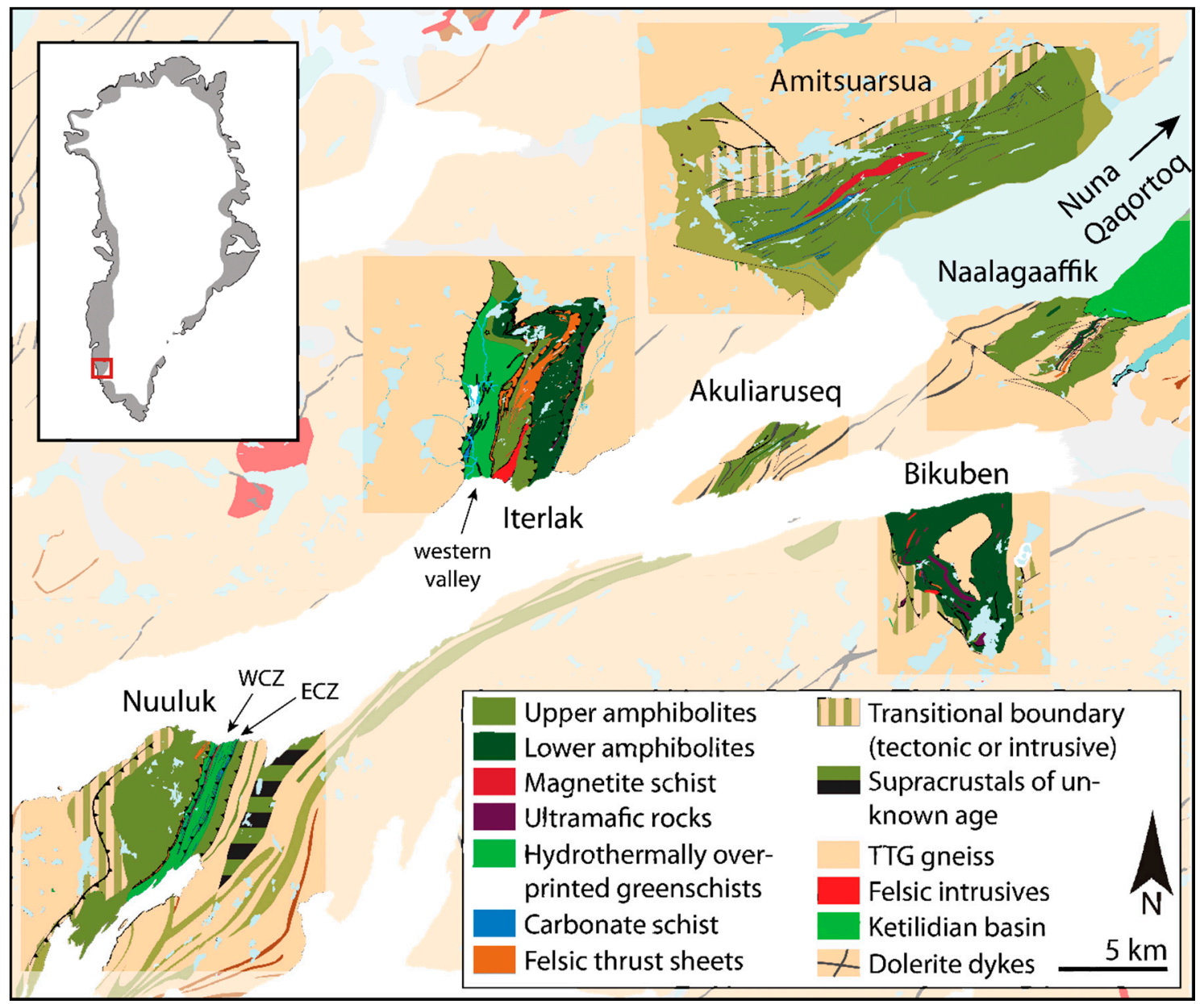

Figure 1. Simplified geological map for the Tartoq Greenstone Belt in SW Greenland showing the locations and geology of the different segments, and of the Western and Eastern Carbonate Zones. Nuna Qaqortoq is located in the inland ice approximately $20 \mathrm{~km}$ to the NE of Amitsuarsua. Modified after [2].

The rocks exposed in the Tartoq belt are predominantly tholeiitic meta-basalts of back- or fore-arc affinity [6]. Metamorphism and deformation have largely overprinted original textures and unit relationships, although gabbroic and pillow textures, as well as dyke and sill relationships can locally be observed. Ultramafic rocks (serpentinites) are the second most common lithology by exposed volume and are regarded as lower crustal cumulates that are genetically related to the basalts [8]. Minor marine sediments were observed in central Nuuluk and northern Iterlak, consisting of thin horizons of 
chert and banded iron formation, respectively, with a maximum thickness of approximately $30 \mathrm{~cm}$. The combined stratigraphy is interpreted as an ophiolite sequence [6].

The structures of the Tartoq belt and its lithologies indicate co-axial burial and exhumation of the belt, consistent with a convergent margin setting [1,7]. Strike-slip structures dominate in Amitsuarsua and Naalagaaffik, as well as for the slivers parallel to the Sermilligaarsuk fjord, whereas thrusting along a series of en-echelon shear zones controls the structures of Nuuluk, Iterlak, and Bikuben. These shear zones were re-activated at a later stage to act as fluid pathways for gold-mineralizing fluids $[1,2,9,10]$.

A preliminary investigation of the metamorphic P-T history of the belt indicates peak metamorphic conditions ranging from lower greenschist facies to anatexis at granulite-facies conditions [2]. This $\mathrm{P}-\mathrm{T}$ path is inconsistent with that of modern-day convergent margins. Kisters et al. [1] reconciled the Tartoq structural and P-T constraints in a model that envisions convergence governed by repeated short-lived subduction. This model critically depends on the accuracy of the reconstructed $\mathrm{P}-\mathrm{T}$ path for the belt, currently only constrained from a small set of samples. Here, we verify and expand on the initial pseudosection study of the P-T conditions by investigating a much larger suite of samples from all fragments of the Tartoq belt and all major rock lithologies with complementary constraints from mineral compositions and geothermobarometry. Retrogression and its impact on calculated P-T constraints is also examined.

\section{Materials and Methods}

Samples of all lithologies were collected during fieldwork in 2009 and 2010. Bulk rock compositions of these samples were determined by flux-digestion ICP-MS on powdered samples. Full details of the analysis method as well as the complete data set are available in $[6,8,11]$. Bulk compositions for samples used in the present study are also listed in Supplementary Table S1. Mineral compositions were determined on polished thin sections by electron microprobe on JEOL 8900RL (JEOL, Peabody, MA, USA) and Cameca SXFiveFE (Cameca, Madison, WI, USA) instruments using wavelength-dispersive spectrometry (WDS) data acquisition at McGill University. Operating conditions were an acceleration voltage of $15 \mathrm{kV}, 20 \mathrm{nA}$ beam current and focused beam with standardization on natural and synthetic minerals. Alkalis were invariably analyzed first to avoid loss by volatilization. Reference minerals were analyzed repeatedly to assess accuracy and precision. Mineral formulae were calculated to the number of cations, except for tourmaline (sum of all cations minus those on the $\mathrm{X}$-site $=15$ ) and amphibole (normalization of [12]).

Pseudosections were calculated in the $\mathrm{Na}-\mathrm{Ca}-\mathrm{Mg}-\mathrm{Fe}-\mathrm{Al}-\mathrm{Si}-\mathrm{Ti}-\mathrm{H}-\mathrm{O}$ system using the Perple_X suite of programs $[13,14]$ using bulk composition constrained Gibbs free energy minimisation. The most recent version of the Holland and Powell thermodynamic database [15] was used for mineral end-members. Mineral solution models were taken from the 2018 Perple_X solution file and are sourced as follows: chlorite, garnet, melt and ilmenite [16], plagioclase [17], epidote, olivine, orthoand clinopyroxene [15], amphibole [18], spinel [19], and antigorite [20].

\section{Results}

Mineral compositions are listed in Supplementary Table S2. The typical precision on homogenous minerals was better than $3 \%$ relative for weight percent levels of all elements except for $\mathrm{F}(8 \%)$, and accuracy, as determined from reference minerals, was better than $5 \%$.

Clino-amphibole compositions are sharply bimodal with actinolite and magnesio-hornblende (+minor ferro-pargasite) modes, which correspond to greenschist- and amphibolite-facies amphiboles, respectively. Actinolite formed by retrogression of hornblende has an intermediate composition at the contact with hornblende relics. Actinolite is characterized by an $\mathrm{X}_{\mathrm{Mg}}$ of $0.70 \pm 0.07$, A-site occupancy $\left(\mathrm{A}_{\text {occ }}\right)$ of $0.06 \pm 0.04$, which is almost exclusively $\mathrm{Na}, \mathrm{Ca} / \mathrm{Na}$ ratio on the M4 site of $52 \pm 44$, and total $\mathrm{Al}$ content of $0.6 \pm 0.3$, whereas the corresponding values for hornblende are $\mathrm{X}_{\mathrm{Mg}}=0.5 \pm 0.1, \mathrm{~A}_{\mathrm{occ}}=$ $0.26 \pm 0.08(85 \% \mathrm{Na}, 15 \% \mathrm{~K}), \mathrm{Ca} / \mathrm{Na}_{\mathrm{M} 4}=12 \pm 3$, and $\mathrm{Al}_{\text {total }}=2.0 \pm 0.4$. Within the actinolite, there is a further division, most clearly seen in $\mathrm{X}_{\mathrm{Mg}}$, with prograde actinolite characterized by lower $\mathrm{X}_{\mathrm{Mg}}$ 
values compared to retrograde actinolite $(0.40 \pm 0.03$ compared to $0.70 \pm 0.07)$ and higher $\mathrm{K}$ contents. The clino-amphibole in samples containing prograde actinolite is also more Fe rich. One sample from Iterlak (512251) contains coexisting clino- and ortho-amphibole. The ortho-amphibole has a cummingtonite composition with a retrograde grunerite rim.

Plagioclase compositions vary significantly from $\mathrm{An}_{15}$ to $\mathrm{An}_{60}$ for peak metamorphic grains in meta-basalts, and down to $\mathrm{An}_{1}$ in retrograde grains. Anorthite-contents as high as $\mathrm{An}_{90}$ are found in calc-silicate rocks. Potassium contents are invariably low with an orthoclase component of less than 0.01 for peak metamorphic plagioclases. Near-endmember K-feldspar is locally observed as a peak metamorphic phase in felsic lithologies and as a retrograde mineral in meta-basalts together with sericite.

Garnet and clinopyroxene have only been measured in two calc-silicate samples, the bulk compositions of which are not representative for the Tartoq belt. Garnet varies in composition between the two samples. In the one, it is a grossular with $8 \%$ uvarovite, $14-22 \%$ andradite, 53-66\% grossular, $5-23 \%$ almandine, $1 \%$ pyrope, and $4-9 \%$ spessartine components. In the other, $5-9 \%$ andradite, $45-54 \%$ grossular, $29-40 \%$ almandine, $1-2 \%$ pyrope, and 7-8\% spessartine components. Most garnet grains are concentrically zoned, particularly in $\mathrm{Mn}, \mathrm{Ca}$, and $\mathrm{Cr}$, with highest $\mathrm{Ca}$ contents consistently found in the garnet core. Mn also decreases from core to rim in most grains, although this is reversed in some. Clinopyroxene grains vary in $X_{\mathrm{Mg}}$ from 0.4 to 0.6 and have minor amounts of $\mathrm{Al}$ (up $0.05 \mathrm{cpfu}$ ).

Chlorite varies in $\mathrm{X}_{\mathrm{Mg}}$ from 0.48 to 0.77 with lower values for prograde and higher values for retrograde chlorite. The $\mathrm{Al}$ content varies from 2.2 to $3.0 \mathrm{cpfu}$. Epidote compositions vary from $\mathrm{Ca}_{2} \mathrm{Al}_{3} \mathrm{Si}_{3} \mathrm{O}_{12} \mathrm{OH}$ to $\mathrm{Ca}_{2} \mathrm{Al}_{2} \mathrm{FeSi}_{3} \mathrm{O}_{12} \mathrm{OH}$ with minor titanium (up to $0.25 \mathrm{wt} \% \mathrm{TiO}_{2}$ ). Ilmenite grains are close to the $\mathrm{FeTiO}_{3}$ endmember with up to $5 \%$ hematite, $7 \%$ pyrophanite, and $0.5 \%$ geikilite. Titanite grains vary in their $\mathrm{Al}+\mathrm{F}$ contents from near endmember $\mathrm{CaTiSiO}_{5}$ to $\mathrm{CaTi}_{0.85} \mathrm{Al}_{0.15} \mathrm{SiO}_{4.85} \mathrm{~F}_{0.15}$.

\section{Tartoq Belt Segments}

Detailed geological maps of the different fragments of the Tartoq belt have been prepared by the geological survey [4,21] and the Renzy, Greenex, and NunaOil companies as part of exploration efforts [9,10,22]. Updated versions of these maps are presented in [2], with cross-sections given in [1].

\subsection{Nuuluk}

Nuuluk represents the easternmost fragment of the Tartoq belt (Figure 1). It is enclosed in amphibolite-facies TTG orthogneisses with a sharp thrust contact at the eastern boundary and a more gradational contact in the west with numerous intrusive TTG sheets and stockworks [1,9]. Nuuluk is dominated by meta-basalts, which are mostly present as well-foliated greenschists. In low strain areas, the greenschists enclose boudins of coarser grained greenstone and meta-gabbro (Figure 2a). A characteristic magnetite-rich meta-basalt is found in central Nuuluk and can be traced for almost $5 \mathrm{~km}$ along strike [2,10]. Primary textures are rare, but sills, dykes, and pillow basalt structures have been locally recognized (e.g., [9]). The greenschists and greenstones contain a dominant metamorphic mineral assemblage of chlorite, albitic plagioclase, quartz, ilmenite \pm epidote \pm actinolite \pm carbonate \pm titanite \pm rutile, and with accessory zircon, apatite, sulfides, and tourmaline (Figure 3a). Both magnetite and ilmenite are present in the magnetite-rich meta-basalt. Relict hornblende and plagioclase are common, especially in greenstones from the eastern and western parts of Nuuluk, which are replaced by actinolite \pm chlorite and albitic plagioclase + epidote respectively. Ilmenite is furthermore replaced by titanite. The ubiquitous occurrence of relict grains suggests that the main greenschist-facies mineral assemblage is a retrograde overprint of an original amphibolite-facies paragenesis. Prograde actinolite is locally preserved in the cores of large hornblende grains (Figure 3c). It contains abundant inclusions of quartz, with lesser chlorite, titanite, epidote, ilmenite, and chalcopyrite. Prograde minerals are characteristically observed in more Fe-rich bulk rock compositions (e.g., 510633 and 510638). 

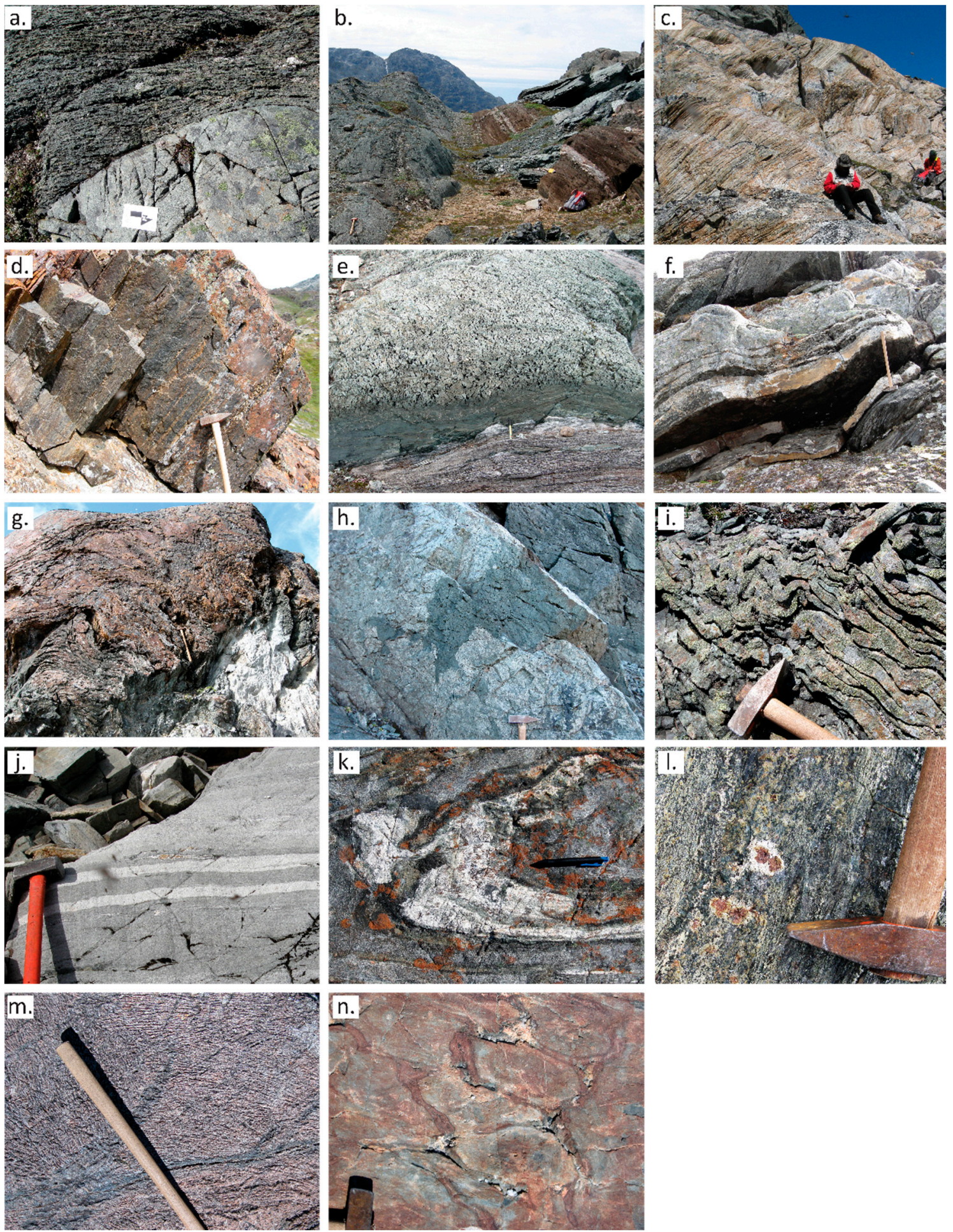

Figure 2. Field photographs of characteristic lithologies and textures in the Tartoq belt; (a) Greenschist with boudins of greenstone in Nuuluk; (b) Overview of the Eastern Carbonate Zone with brown chlorite-ankerite schists at the base of the shearzone; (c) Felsic mylonite in Nuuluk; (d) Laminated chert horizon in southern Nuuluk; (e) Metasomatic reaction zone between knobbly greenschist (at top) and ultramafic rock in Iterlak with grey talc schist and green actinolite zone; (f) Felsic thrust sheet in Iterlak with talc schists at its base; (g) metasomatic iron formation adjacent to talc schist in eastern Iterlak; (h) Mingling textures in Amitsuarsua amphibolite; (i) Weathered out carbonate in between the greenschist foliation; ( $\mathbf{j}$ ) Compositional variations in Bikuben amphibolite; (k) Anatectic melts pooling in, and breaking through fold hinges in Bikuben; (l) Leucocratic rims on garnet in Bikuben calc-silicate rocks; (m) Pseudo-spinifex texture in Bikuben ultramafic rock; (n) Pillow textures in Nuna Qaqortoq amphibolites. 

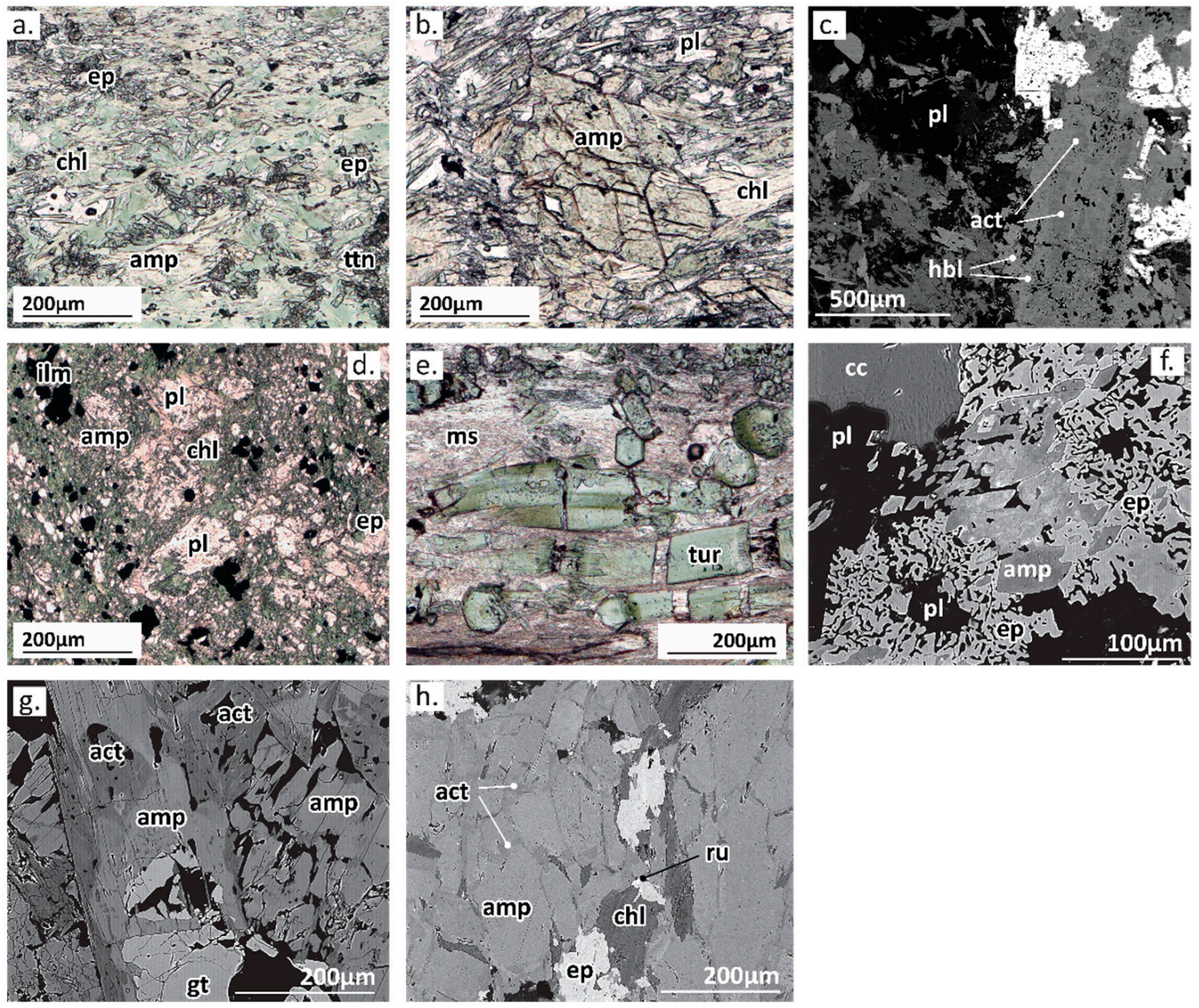

Figure 3. Micrographs and backscattered electron images of characteristic textures in Tartoq belt rocks; (a) Typical Nuuluk greenschist with chlorite, epidote, plagioclase, quartz, titanite and relics of amphibole and ilmenite; (b) Greenschist from southern Iterlak showing an amphibole porphyroblast; (c) Prograde actinolite rimmed by magnesio-hornblende in a Nuuluk greenstone; (d) Retrograded Iterlak gabbro with dark green amphibole being replaced by lighter green chlorite, but with preservation of the gabbroic texture; (e) Concentrically and sector zoned tourmaline in a sample of fuchsite schist adjacent to a quartz-ankerite vein in the Eastern Carbonate Zone of Nuuluk; (f) Typical texture of the actinolite-epidote-titanite retrogression stage; (g) Texture of a calc-silicate sample from Bikuben with retrograde replacement of hornblende by actinolite; (h) Well preserved amphibolite. Thin rims of actinolite and a vein of chlorite and epidote mark later retrogression. Mineral abbreviations used: $\mathrm{amp}=$ hornblende amphibole; act = actinolite; chl = chlorite; ep = epidote; $\mathrm{ttn}=$ titanite, $\mathrm{cc}=$ calcite; $\mathrm{pl}=$ plagioclase $; \mathrm{gt}=$ garnet tur = tourmaline, $\mathrm{ru}=$ rutile; ilm = ilmenite; $\mathrm{ms}=$ muscovite .

The central part of Nuuluk is characterized by a series of sub-parallel shear zones and associated carbonation and retrogression of the host greenschists (Figure 2b). Calcite is introduced as lenses and pods sub-parallel to the chlorite foliation with the calcite mode progressively increasing towards the shear zones. Where this calcite has been weathered out, the outcrops take on a characteristic vuggy or knobbly texture. In addition to the carbonation, any remaining plagioclase is converted to near end-member albite $\left(X_{\mathrm{Ab}}>0.97\right)$, ilmenite is replaced by titanite, and muscovite, commonly with a high fuchsite component, is introduced. The shear zones themselves, referred to as the Eastern and Western Carbonate zones in earlier work (ECZ and WCZ) consist of anastomosing networks of quartz + ankerite veins, with variable amounts of pyrite [9,10,22]. A schist rich in fuchsite is commonly present on vein walls and locally contains tourmaline and/or talc (Figure 3e). The sulfidic horizons are enriched in gold $[9,10,22]$. 
A distinct felsic mylonite sheet is present in central Nuuluk (Figure 2c) and marks the transition from the western greenschist plateau to the WCZ (Figure 1). Although initially interpreted as a felsic tuff and part of the Tartoq stratigraphy (e.g., [10]), we interpret it to represent enclosing TTG gneiss that has been thrust into the Tartoq along the shear zone during imbrication [2]. This interpretation is also supported by bulk rock geochemical data [6], as well as our unpublished U-Pb zircon dates with ages (main modes at 2.85 and $2.9 \mathrm{Ga}$ ) that overlap with the regional TTG orthogneisses. The mylonite has a mineral paragenesis of quartz + muscovite + albitic plagioclase \pm chlorite. Locally, relict K-feldspar is present and it appears that the muscovite dominantly represents K-feldspar replacement. Muscovite schists are further observed associated with the WCZ and ECZ. These are dominated by muscovite and quartz with lesser K-feldspar, biotite (being retrogressed to chlorite), rutile, and titanite. Allanite, zircon, pyrite, and apatite are present as accessory phases. It is unclear what these muscovite schists represent. Petersen $[10,22]$ regards them as a primary, felsic lithology. However, their close association with the WCZ and ECZ suggests they could rather have formed as part of the hydrothermal fluid overprinting.

A dense unit of silicified rock is present in south central Nuuluk (Figure 2d), composed predominantly of quartz with pyrite, tourmaline and chlorite. This unit is up to $30 \mathrm{~cm}$ thick and can be traced along strike for at least $100 \mathrm{~m}$. The unit lacks carbonate, which makes it distinct from hydrothermally altered lithologies in the WCZ and ECZ. It potentially represents submarine exhalative chert (cf., $[23,24])$.

\subsection{Iterlak}

Iterlak consists of a central plateau of meta-basaltic greenschists and amphibolites, bordered in the east by a valley with a sharp tectonic boundary to the enclosing TTG gneisses (Figure 1). A broad valley occupies the western part of Iterlak. The contact with the TTG gneisses in the west and northwest consists of a narrow band with multiple tectonized intrusive sheets of TTG gneiss. The western valley hosts abundant pyrite-rich horizons in a muscovite schist, accompanied by strong retrogression of the meta-basalts and local carbonation $[9,10,22]$. A smaller pyrite + carbonate + muscovite zone is present at the southern end of the eastern valley $[10,22,25]$.

The dominant lithologies in Iterlak are meta-basaltic greenschists and amphibolites. The greenschists are equivalent to those in Nuuluk, with identical mineralogy and textures and are mostly found adjacent to the western valley. Greenschists are also found along the shore of the Sermilligaarsuk fjord, where they locally show prograde amphibole porphyroblasts (Figure 3b). Amphibolites are present as boudins and layers within the greenschists, and progressively as massive amphibolites towards the northeast. Gabbroic textures are common in the amphibolites in the north and east. The amphibolites show, from lower to higher metamorphic grades, the mineral parageneses amphibole + plagioclase + quartz + chlorite + epidote + ilmenite, amphibole + plagioclase + quartz + epidote + ilmenite, and amphibole + plagioclase + quartz + ilmenite. Apatite is the dominant accessory phase. Retrogression of the amphibolites is widespread, although variable in intensity, and is characterized by replacement of amphibole by actinolite and eventually chlorite, albitization of the plagioclase, re-introduction of abundant epidote, and replacement of ilmenite by titanite (Figure $3 \mathrm{~d}, \mathrm{f}, \mathrm{h}$ ). Calcite is also commonly introduced. Given the location of the Iterlak greenschists as a band around the western valley with its abundant hydrothermal deposits (Figure 1), it is conceivable that most of the greenschists represent retrogressed amphibolite, with the exception of the greenschists along the southern shore of Iterlak.

Lenses and layers of calc-silicate composition are common in the amphibolites of Iterlak, generally with a gradational contact to the host amphibolite. The typical mineral paragenesis is amphibole + plagioclase + clinopyroxene + quartz + ilmenite + carbonate \pm garnet. The amphibole in most of the calc-silicates is clino-amphibole, although in some both clino- and ortho-amphibole was observed. Retrograde overprinting is commonly extensive and leads to replacement of plagioclase by epidote + albite, garnet and pyroxene by epidote and actinolite, hornblende by actinolite, and ilmenite by titanite (Figure 3g). A second generation of calcite is also introduced, mostly as veins. 
Ultramafic lenses are common in northern and eastern Iterlak and range in size from meters to 100 meters [2,8]. These bodies consist of a core of serpentinite, dominantly composed of antigorite and spinel, enclosed by a talc-magnetite-carbonate rim. The serpentinite core is not always observed. A mono-mineralic actinolite zone is generally present at the contact with the enclosing meta-basalts (Figure 2e). Shear concentrates in the talc schists owing to their low competence and, as a result, the talc schists have been sheared out into thin horizons that can be traced for over $5 \mathrm{~km}$ throughout Iterlak (Figure 1), and commonly occur at the base of thrusts (e.g., Figure 2f). Interaction with the enclosing mafic rocks during shearing and thinning produces a rock unit composed of magnetite + quartz \pm grunerite, commonly layered or laminated, that has the appearance of a banded iron formation (cf., $[10,25])$. However, its genetic link with the serpentinites is clear from the close spatial association with talc schists (Figure $2 \mathrm{~g}$ ) and the gradual transition when tracing the unit along strike. During retrogression, Fe-sulfides-both pyrite and pyrrhotite-locally replace magnetite.

A small sedimentary banded iron formation was identified in northern Iterlak consisting of an approximately $5 \mathrm{~cm}$ thick, banded lithology of alternating magnetite and quartz within a light pink muscovite schist. It could be traced for several tens of meters along the outcrop. This banded iron formation (BIF) layer contains what appear to be angular dropstones (cf., [24]). The presence of sedimentary textures differentiates this unit from the metasomatic banded magnetite material found associated with sheared ultramafic lenses.

Felsic lithologies are common in central Iterlak (Figure 1) and consist of an intrusive body in the south, which provides the 2.9 Ga minimum age for the Tartoq $[5,11]$, and shear zone bounded felsic gneisses in the central and northeastern parts. The latter are well-foliated quartz-feldspar-muscovite schists and mylonites, and are similar to the felsic mylonites of central Nuuluk. The strong deformation of this unit has completely obliterated original textures. Petersen [10] regards these as volcanic tuffs interbedded with the basalts, but we prefer an interpretation as TTG gneisses that were sheared into the Tartoq during imbrication as we also suggested above for Nuuluk. This interpretation is based on the observation that these felsic units are invariably associated with shear zones that juxtaposition different mafic and ultramafic Tartoq lithologies and are discordant with these (ultra)mafic lithologies; they mark the relatively sharp boundary between the lower and higher grade amphibolites in Iterlak (Figure 1); and the zircon ages for this felsic unit overlap with those of the enclosing TTG gneisses.

\subsection{Amitsuarsua}

Amitsuarsua is the largest Tartoq fragment. Whereas the structures in Nuuluk and Iterlak are dominated by shear zones, strike-slip motion dominates in Amitsuarsua and deformation is less intense. The northern border of Amitsuarsua consists of a broad zone with TTG intrusive sheets and breccias into greenstones and amphibolites. The other contacts are not well defined. The main lithologies are meta-basaltic greenstones, greenschists, and amphibolite with the dominant mineral parageneses chlorite + plagioclase + quartz + ilmenite \pm epidote \pm titanite, chlorite + amphibole + quartz + ilmenite \pm epidote \pm titanite and amphibole + plagioclase + quartz + ilmenite \pm epidote. There is compositional variability in these mafic rocks, which is expressed as variations in the amphibole/chlorite versus plagioclase modes. In one location (UTM zone 22N: 644174E, 6835966N), apparent igneous mingling can be observed between a mafic and more felsic melt, now both metamorphosed to amphibolite (Figure 2h). A magnetite-rich greenstone is present in the central part of Amitsuarsua and is equivalent to the magnetite-rich mafic schists of Nuuluk. It is unfoliated, but appears concordant with the enclosing greenschists. Retrogression results in introduction of carbonate and local replacement of magnetite by pyrite. Gabbroic and pillow textures are locally observed. Carbonation of the greenschists, as observed in Nuuluk and Iterlak, is present, but is less pervasive (Figure 2i). The carbonates do form much larger accumulations, including a dolomite body in excess of $50 \mathrm{~m}$ in central Amitsuarsua (Figure 1). Previous studies suggested this to be primary carbonate [10], but the dolomite can be observed infiltrating the greenschist foliation and wedging it 
apart (Figure 2i), indicating it to be secondary and related to the carbonation observed throughout the Tartoq belt. Where these carbonates have subsequently weathered out, the rocks obtain the characteristic knobbly appearance. Retrogression is locally intense with replacement of amphibole by chlorite, albitization of plagioclase, and introduction of carbonate, epidote, fuchsite \pm pyrite. Quartz, carbonate and epidote veining accompanies the retrogression.

Few other lithologies are observed in Amitsuarsua. In particular, felsic schists, such as those observed in Nuuluk and Iterlak, are absent, which is difficult to reconcile with these being an integral part of the Tartoq stratigraphy. It rather supports their origin as foreign material sheared into the Tartoq, given the lack of thrusting tectonics in Amitsuarsua. A body of serpentinite is present in northern Amitsuarsua enclosed in a talc-ankerite-magnetite schist, which is discussed in detail in Szilas et al. [8].

\subsection{Bikuben}

The Bikuben fragment consists of a sequence of mafic to leucocratic amphibolites, meta-gabbros, and ultramafic rocks. The fragment is bordered in the west by an up to $2 \mathrm{~km}$ wide tectonic mélange of retrogressed amphibolites and TTG gneisses, reworked by cataclasites, and intruded by abundant pegmatite sheets. Its central and eastern contacts are shear zones. The amphibolites and meta-gabbros lack a strong foliation and contain a mineral paragenesis of amphibole + plagioclase + ilmenite + quartz \pm garnet \pm clinopyroxene. The amphibolites show strong and abrupt color and mineral mode variations (Figure 2j), which represent compositions from dioritic to gabbroic, and are interpreted to represent primary compositional variability. Partial melting of the amphibolites has been observed in two locations in Bikuben, accompanied by melt mobility into fold hinges (Figure 2k). Partial melting has also been reported by Evans and King [9].

Calc-silicates are common in Bikuben. Although the largest is still only $10 \mathrm{~m}$ in width, most occur as meter-sized lenses and concordant layers within the amphibolites. They have a mineral paragenesis of clinopyroxene + garnet + amphibole + plagioclase + ilmenite + quartz \pm carbonate Locally, garnet has leucocratic melt rims (Figure 21). The garnet has an irregular rim at its contacts with the melt, suggesting that it is breaking down as part of the partial melting reaction.

Ultramafic rocks are common as a series of boudinaged lenses of serpentinite with a thin rim of talc-magnetite-ankerite schist. The serpentinites are composed of antigorite + magnetite \pm brucite, which enclose relict olivine, tremolite, Cr-spinel, and anthophyllite. A mono-mineralic layer of coarse-grained green amphibole (crystals up to $5 \mathrm{~cm}$ in length) is found at the contact with the host amphibolites, whereas biotite is present at contacts with late undeformed pegmatite dykes. One of the ultramafic bodies displays a pseudo-spinifex texture as defined by magnetite grains outlining what likely was anthophyllite (Figure $2 \mathrm{~m}$ ).

Retrogression is largely confined to zones of deformation and to the contacts with the enclosing TTG gneisses. In the amphibolites and gabbros it varies in intensity from complete replacement by a chlorite \pm carbonate schist, to subtle chloritization of amphibole. The calc-silicates generally show more intense retrogression with epidote replacing garnet, amphibole, and plagioclase; albitization of plagioclase; and replacement of ilmenite by titanite. Quartz, carbonate, epidote, and black amphibole veining accompanies the retrogression.

\subsection{Other Blocks}

Akuliaruseq and Naalagaaffik are structurally similar to Amitsuarsua and dominated by strike-slip motion, as are the slivers along the Sermilligaarsuk fjord east of Nuuluk. The structural setting of Nuna Qaqortoq is still unclear. Akuliaruseq and Naalagaaffik dominantly consist of meta-basaltic greenschists and amphibolites, minor gabbros, leuco-gabbros, and ultramafic lenses, the latter mainly as talc-magnetite-carbonate schists enclosing small (up to $10 \mathrm{~m}$ ) serpentinite bodies. The serpentinites are composed of antigorite, magnetite and brucite, locally with relict tremolite, olivine, and $\mathrm{Cr}$-spinel. The greenschists mostly represent retrogressed amphibolites as evidenced from 
chlorite pseudomorphs after amphibole and amphibole relics, sometimes as augen in a chlorite-schist. Retrogression is most intense close to deformation zones and is accompanied by carbonate, quartz, and epidote veining. In Naalagaaffik the ultramafic lenses are found in a central, roughly $\mathrm{E}-\mathrm{W}$ band together with the (leuco-)gabbros, and this band is separated from the amphibolites and greenschists to the north and south by felsic gneisses and mylonites. This central unit potentially represents a klippe with felsic, TTG-derived mylonite at its base. A $15 \mathrm{~cm}$ thick BIF of alternating magnetite and quartz was found in central Akuliaruseq, which has sedimentary textures similar to those observed for the BIF in Iterlak, including dropstones. The layer occurs adjacent to a pink sericite-quartz schist.

Retrogression is less pronounced on Nuna Qaqortoq and amphibolites, locally with pillow textures (Figure 2n), are well preserved (see also [21]). Amphibolites contain amphibole + plagioclase + quartz + ilmenite and vary from amphibole to plagioclase dominated. Minor retrogression introduces carbonate, epidote, titanite, and chlorite. A fine-grained ultramafic body on Nuna Qaqortoq contains olivine, tremolite, anthophyllite and Cr-spinel in an antigorite-brucite-magnetite matrix, and is cut by anthophyllite veins. It has a biotite blackwall at its contact with an intrusive pegmatite sheet.

The slivers of Tartoq parallel to the Sermilligaarsuk fjord to the east of Nuuluk are predominantly composed of greenschists with a mineral paragenesis of chlorite + plagioclase + quartz + ilmenite + epidote. Locally, lenses of greenstone are present with a paragenesis of chlorite + actinolite + plagioclase + quartz + ilmenite. Epidote veining is common and crosscuts the foliation.

\section{Constraining Metamorphic Conditions}

Metamorphic grade in the Tartoq belt is dominated by lower to upper amphibolite facies conditions. Granulite facies conditions are locally encountered in Bikuben and associated with partial melting (Figure 2k). Minor primary greenschist facies parageneses are found in Nuuluk, southern Iterlak, and the slivers south of the Sermilligaarsuk fjord, but the majority of greenschist assemblages reflect retrograde re-equilibration that is spatially associated with shear zones and hydrothermal activity.

The extensive retrogression observed in the Tartoq belt lithologies complicates constraining the metamorphic pressure-temperature conditions. Peak metamorphic minerals commonly show partial retrograde re-equilibration with albitization of plagioclase and patchy replacement of peak amphibole by actinolite (e.g., Figure 3f,g). This retrograde overprint takes place under chemically open-system conditions as evidenced by the resulting hydration of the rocks and the introduction of locally abundant carbonate. Moreover, the retrograde replacement reactions do not chemically balance. The present bulk rock composition may therefore differ from that in which the peak metamorphic minerals equilibrated. Still, peak metamorphic mineral parageneses can be reconstructed for the majority of Tartoq belt lithologies from mineral relics. This allows for determining metamorphic conditions from pseudosection modelling and geothermobarometry.

\subsection{Plagioclase-Amphibole and Plagioclase-Amphibole-Garnet-Clinopyroxene Geothermobarometry}

Peak metamorphism is constrained to $630 \pm 45^{\circ} \mathrm{C}$ from thermometry on 46 plagioclase-amphibole mineral pairs from 9 samples using the equations of [26] (see Supplementary Table S3 for results). There is no systematic difference in calculated temperatures for samples from Nuuluk, Iterlak, and Bikuben, which is surprising given the somewhat lower grade conditions in Nuuluk and the partial melting observed in Bikuben. The range in temperatures for a given sample is large (up to $100^{\circ} \mathrm{C}$ ), which indicates that compositional overprinting from later retrogression is present for at least some mineral pairs.

The presence of garnet in Bikuben allows for pressure to be constrained in addition to temperature by combining the plagioclase-amphibole [26,27], plagioclase-amphibole-garnet-quartz [28], garnet-amphibole [29], and garnet-clinopyroxene [30] thermobarometers for the peak mineral paragenesis. Conditions are estimated at 625 to $665 \pm 90{ }^{\circ} \mathrm{C}$ at $7.5 \pm 1$ kbar (results in Supplementary Table S3). 


\subsection{Tourmaline Thermometry}

Tourmaline is mostly constrained to the gold-mineralized alteration zones in Iterlak and Nuuluk where it is concentrated at the contact with quartz-ankerite veins. One, mm-sized tourmaline grain was found in an amphibolite in Bikuben in textural equilibrium with magnesio-hornblende and plagioclase. Tourmaline-plagioclase thermometry [31] gives a temperature of $650 \pm 30^{\circ} \mathrm{C}$ for peak metamorphic pairs in Bikuben, and $380 \pm 20^{\circ} \mathrm{C}$ for the alteration related tourmalines (see also [2] and Supplementary Table S3). Sector zoning was moreover observed in the latter tourmalines, which gives a temperature of $375 \pm 50^{\circ} \mathrm{C}$ using the thermometric formulation of [32] (Supplementary Table S3). Tourmaline inter-sector thermometry requires a $\mathrm{Ca}$ and a Ti saturating phase assemblage in order for the equilibrium sector concentrations to be attained. These conditions are satisfied for the hydrothermal stage by the mineral assemblage calcite + titanite + quartz \pm rutile.

\subsection{Pseudosection Modelling}

Pseudosections provide pressure-temperature constraints in two ways: (1) They locate the sample paragenesis in $\mathrm{P}-\mathrm{T}$ space and thereby provide a field of $\mathrm{P}-\mathrm{T}$ conditions for a specific sample, which can be narrowed down further by overlaying the P-T fields of multiple, cogenetic samples; and (2) They allow for mineral compositional contours (isopleths) to be plotted in P-T space to locate the mineral compositions as measured in the samples. Combining these two approaches can allow for precise $\mathrm{P}-\mathrm{T}$ estimates to be obtained. Unfortunately, the isopleth method commonly fails to converge for Tartoq rocks, likely related to (partial) compositional overprinting of mineral compositions during the various retrogression events that have affected the belt. Peak metamorphic bulk compositions can be reconstructed from the compositions and estimated modes of relict peak metamorphic minerals. We explored this for Tartoq amphibole-plagioclase-ilmenite-quartz amphibolites where the simple mineralogy allows for reasonably robust mode estimates from thinsection microscopy and EDS imaging (cf., [33]). The change in bulk composition is small (see Supplementary Table S1). It increases the stability field of the peak paragenesis, especially towards higher pressures by suppressing the appearance of garnet. However, the region within the field that is relevant for the observed peak metamorphic mineral compositions remains essentially the same. There is better agreement between measured mineral compositions and calculated isopleths, although no convergence between $\mathrm{Al}$ content, $\mathrm{X}_{\mathrm{Mg}}$, and $\mathrm{Ca} / \mathrm{Na}$ ratio for amphibole. The better isopleth agreement is to be expected given that the mineral compositions are used to calculate the new bulk composition and this is therefore partly imposed. Given that the pseudosection field constraints for the peak mineral parageneses did not change markedly between measured and reconstructed bulk compositions, we regard the P-T constraints that these provide as the most robust.

Pseudosection modelling requires $\mathrm{H}_{2} \mathrm{O}$-activity and $f \mathrm{O}_{2}$ to be imposed, either by setting these to a fixed quantity, or by buffering them by a phase assemblage. Here, coexisting magnetite and ilmenite in the magnetite-schists of Nuuluk, Iterlak, and Naalagaaffik allows for estimating the $\mathrm{fO}_{2}$ during metamorphism. The two oxides occur in direct contact in the matrix and as reciprocal inclusions, with inclusion and matrix compositions being identical within error, indicating equilibrium. Using the formulation of Andersen and Lindsley [34] gives a consistent $\log f \mathrm{O}_{2}$ of $-17 \pm 0.5$ at $580 \pm 35^{\circ} \mathrm{C}$ for the various samples, which corresponds to a $\log \mathrm{fO}_{2}$ of approximately $\mathrm{Ni}-\mathrm{NiO}+1$. The pseudosections were therefore buffered to a $\log f \mathrm{O}_{2}$ of $\mathrm{NNO}+1$. An oxygen fugacity of $\mathrm{NNO}-2$ was chosen for the ultramafic rocks to reflect more reducing conditions that result from serpentinization. Water activity varies among the calculations. For greenschists and amphibolites, fluid-saturation was assumed with an $\mathrm{X}\left(\mathrm{CO}_{2}\right)$ of 0.05 . For the retrograde stage, fluid saturation is clear, because the retrogression is accompanied by metasomatism and hence takes place under open-system, and likely fluid-mediated, conditions. The prograde greenschist to amphibolite-facies metamorphism also likely takes place under fluid-saturated conditions given that the minerals that form progressively contain less water, and metamorphism is therefore accompanied by fluid generation. Whether the anatexis observed in Bikuben took place under water-saturated conditions is unclear. It was therefore modelled for a 
range of water contents, from half the amount currently present in the rock (assuming all LOI to be water) to water-saturated. The impact on the pseudosection topology is minimal and the main changes due to varying water content are in the mineral modes and melt volume.

Pseudosections inherently depend on the thermodynamic end-member data and solution models chosen to calculate mineral stability. Here we use the most up to date version of the Holland and Powell database [15] in conjunction with an internally consistent set of solution models (see Section 2 for details). The solution models of Green et al. [35] provide an alternative internally consistent set that allows for the robustness of the pseudosections presented here to be evaluated. The results are equivalent with the solidus shifting by less than $20^{\circ} \mathrm{C}$ and a $\Delta \mathrm{P}<0.5 \mathrm{kbar}$ and $\Delta \mathrm{T}<20^{\circ} \mathrm{C}$ for the amphibolite peak parageneses. This indicates that the mineral stability fields, and the $\mathrm{P}-\mathrm{T}$ constraints that they provide, are robust and essentially model-independent.

\subsubsection{Greenschists}

Twenty-two pseudosections were calculated for prograde and retrograde greenschist assemblages over the full range of Tartoq bulk compositions, and typical examples of these pseudosections are shown in Figure 4. The topology of the greenschist pseudosections does not change significantly with the differences in bulk compositions observed for the Tartoq samples. The mineral paragenesis for the Nuuluk prograde greenstone sample 510638 constrains conditions to a narrow field of temperature from 420 to $470{ }^{\circ} \mathrm{C}$ and a pressure of $<4.5 \mathrm{kbar}$ as controlled by the coexistence of actinolite, chlorite, plagioclase, titanite, and epidote (Figure $4 \mathrm{~b}$ ). Ilmenite, rather than titanite, is the Ti-phase in the prograde greenschists of southern Iterlak and a Nuuluk greenstone sample, which suggests somewhat higher temperatures and a pressure between 2.5 and 4.5 kbar (Figure 4c).

The retrograde greenschists have a typical mineral paragenesis of chlorite + epidote + titanite + quartz + albite + calcite ( \pm apatite, tourmaline, sulfides, and graphite). This same paragenesis is also observed as a retrograde assemblage in amphibolites in all fragments of the Tartoq. The paragenesis is observed in the pseudosections at around $375{ }^{\circ} \mathrm{C}$ at $1 \mathrm{kbar}$ to $450{ }^{\circ} \mathrm{C}$ at $4.5 \mathrm{kbar}$ (region $\mathrm{D}$ in Figure $4 \mathrm{~d}$ ). Tourmaline thermometry overlaps with this band at low pressure. Several of the most intense hydrothermally overprinted samples lack epidote and titanite, and have a mineral assemblage that plots in field E of Figure 4, dominated by chlorite, quartz, carbonates, and rutile suggesting a temperature below $350{ }^{\circ} \mathrm{C}$.
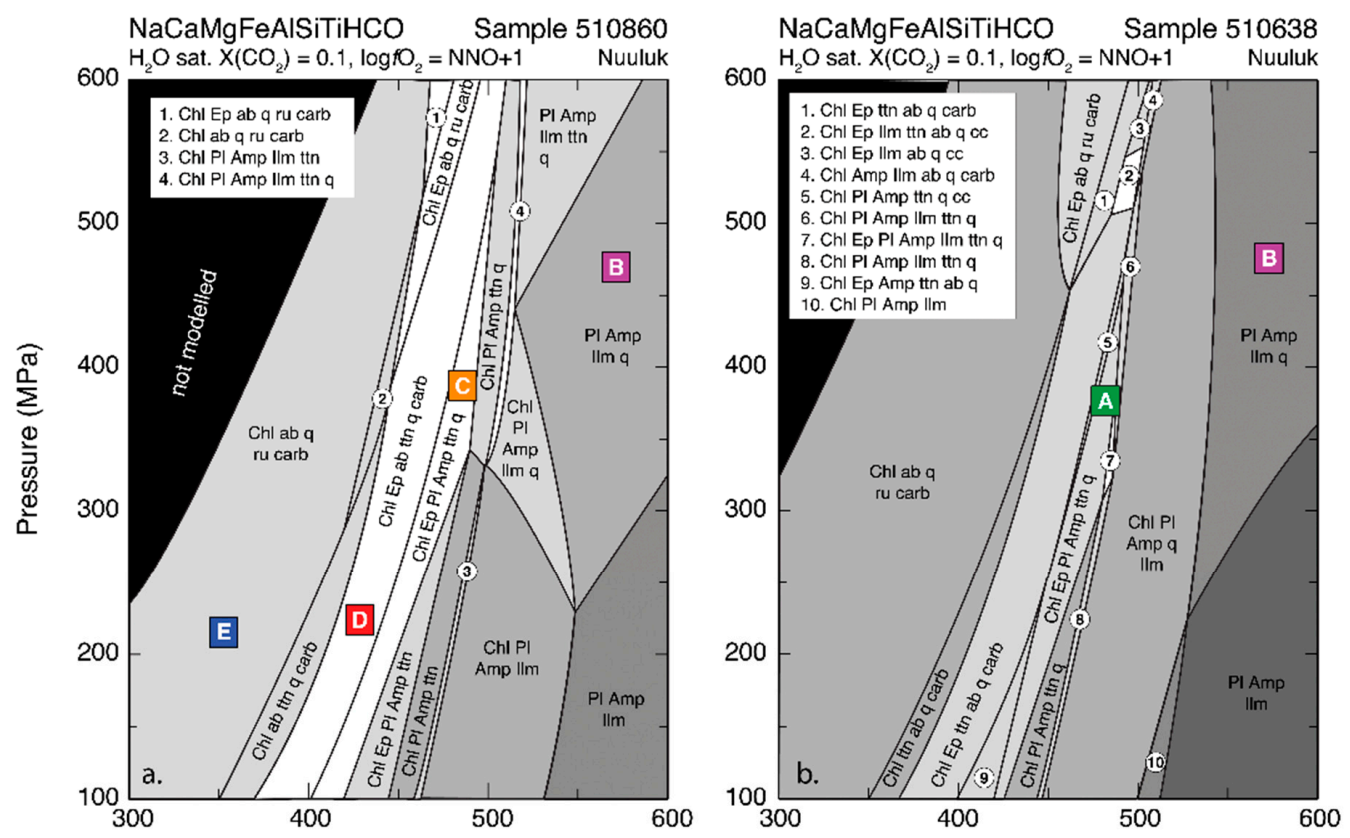

Figure 4. Cont. 

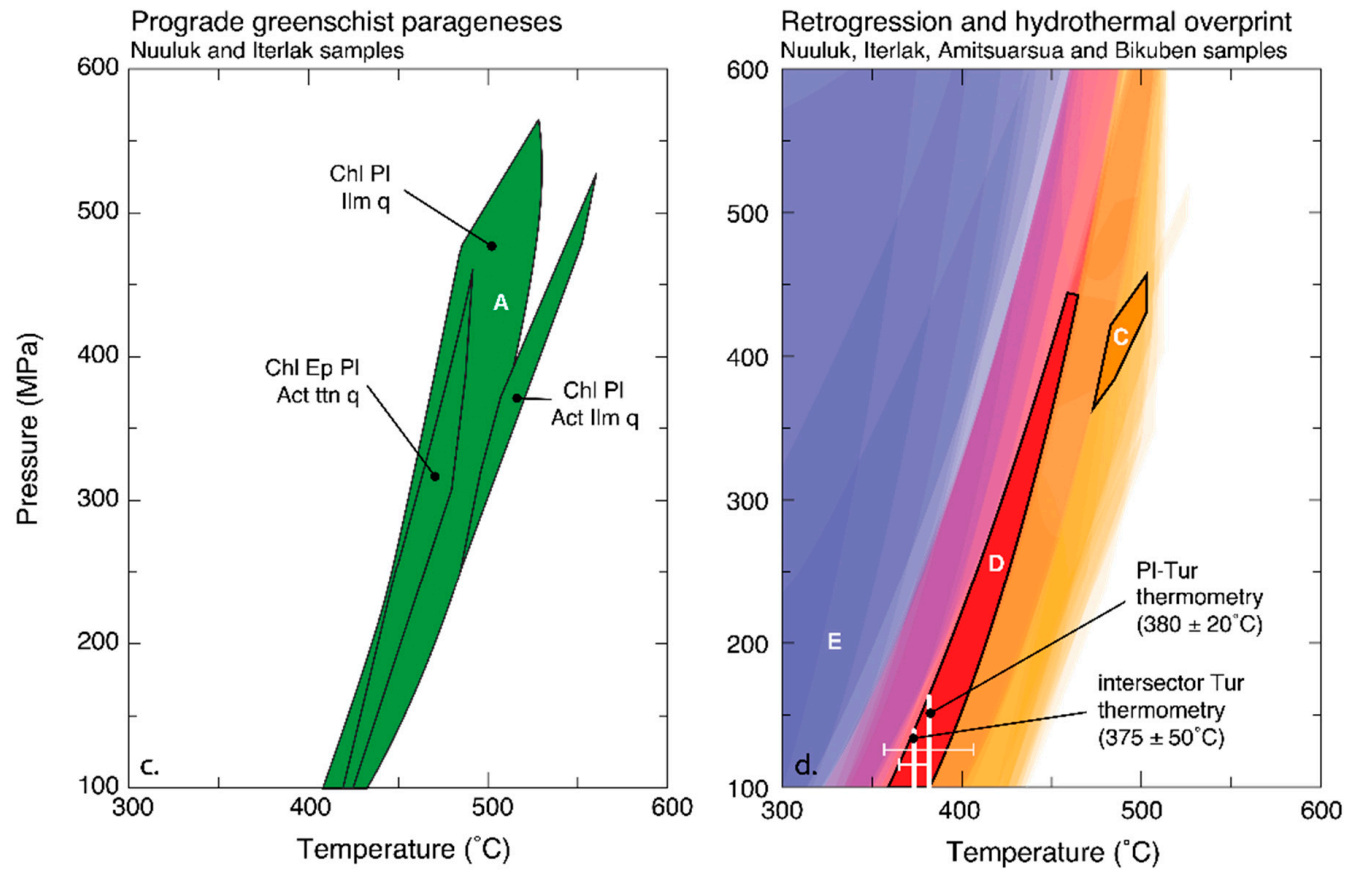

Figure 4. Pseudosection results for Tartoq greenschist assemblages; (a) Typical retrograde Nuuluk greenschist with peak conditions in the amphibolite field $\mathrm{B}$ as defined by mineral relics and progressive retrograde assemblages from field $\mathrm{C}$ to $\mathrm{E} ;(\mathbf{b})$ Prograde Nuuluk greenschist (field A) with peak paragenesis at B; (c) Pseudosection fields for all prograde greenschist-facies parageneses from Nuuluk and Iterlak; (d) $\mathrm{P}-\mathrm{T}$ constraints for successive retrograde assemblages from overlapping pseudosection for all retrograde assemblages compared to tourmaline thermometry results. Minerals starting with a capital letter were modelled as a solid solution. Mineral abbreviations as in Figure 3 and carb $=$ carbonate.

\subsubsection{Amphibolites}

Despite significant variations in bulk rock composition, the mineral parageneses of the amphibolites are similar, and variations are mostly limited to differences in mineral mode and composition. Typical pseudosections are shown in Figures 5 and 6. The main amphibolite peak mineral parageneses observed in the Tartoq belt are:

a. Clino-amphibole + plagioclase + epidote + quartz + ilmenite

b. Clino-amphibole + plagioclase + quartz + ilmenite

c. Ortho- + clino-amphibole + plagioclase + quartz + ilmenite

d. Clino-amphibole + plagioclase + garnet + quartz + ilmenite

Overlaying the pseudosections from rocks with the same paragenesis but different bulk composition constrains paragenesis a to ca. $450{ }^{\circ} \mathrm{C}$ at 2 to $6 \mathrm{kbar}, \mathrm{b}$ to $>550{ }^{\circ} \mathrm{C}$ at 3.5 to $7 \mathrm{kbar}$ (Figures $5 \mathrm{c}$ and $6 \mathrm{c}$ ), and $\mathrm{d}$ to $\sim 700{ }^{\circ} \mathrm{C}$ at $7.5 \mathrm{kbar}$ (Figure 6). Paragenesis $\mathrm{c}$ is found at $>500{ }^{\circ} \mathrm{C}$ at $<6$ kbar. When $\mathrm{MnO}$ is included for the garnet-bearing amphibolite paragenesis, the low-pressure limit shifts down to approximately 7 kbar. The pseudosection constraints are within error of the geothermometry results.

The calc-silicate compositions are characterized by the presence of clinopyroxene, in addition to amphibole, quartz, calcite, and ilmenite. Garnet is present in high-grade samples. Neither wollastonite nor olivine was observed. Using the peak temperature for associated meta-basaltic amphibolites, this indicates an $\mathrm{X}\left(\mathrm{CO}_{2}\right)$ between 0.05 and 0.2 for Iterlak, and $>0.08$ for Bikuben calc-silicates. A typical calc-silicate pseudosection calculated for an $\mathrm{X}\left(\mathrm{CO}_{2}\right)=0.1$ is shown in Figure 6a. The mineral parageneses found in Iterlak and Bikuben are located in a field of $550-750{ }^{\circ} \mathrm{C}$ at $<7 \mathrm{kbar}$ for Iterlak and $600-750{ }^{\circ} \mathrm{C}$ at $7-10 \mathrm{kbar}$ for Bikuben, consistent with $\mathrm{P}-\mathrm{T}$ estimates for the enclosing amphibolites. 
The retrograde amphibolite-facies paragenesis actinolite-chlorite-plagioclase-epidote-titanite-quartz is positioned in the pseudosections over a range of conditions from 350 to $450{ }^{\circ} \mathrm{C}$ at $1 \mathrm{kbar}$ to 450 to $500{ }^{\circ} \mathrm{C}$ at $6 \mathrm{kbar}$ (field $\mathrm{C}$ in Figure 4). This paragenesis is unconstrained in pressure for most samples with the exception of sample 510722, which tightly constrains the pressure for this stage to 4 kbar by the coexistence of plagioclase and epidote (Figure $4 \mathrm{~d}$ ).
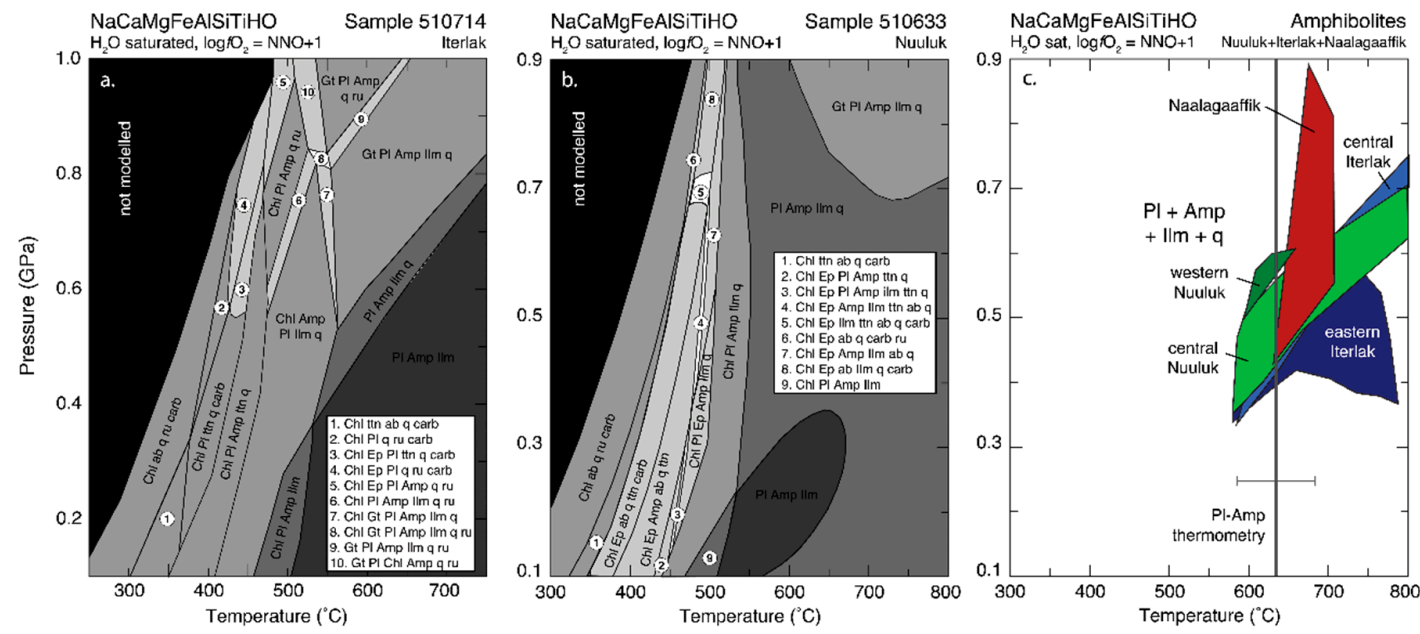

Figure 5. Pseudosection results for Tartoq amphibolite-facies assemblages; $(\mathbf{a}, \mathbf{b})$ Typical pseudosections for Iterlak and Nuuluk amphibolites with a pl-amp-ilm-q peak paragenesis; (c) Compilation of all pseudosection fields for the pl-amp-ilm-q amphibolite-facies parageneses in Nuuluk, Naalagaaffik and Iterlak, where the boxes represent the P-T constraints from the overlap in these fields. Plagioclase-amphibole thermometry is in good agreement with pseudosection constraints. Minerals starting with a capital letter were modelled as a solid solution. Mineral abbreviations as in Figure 3 and $c a r b=$ carbonate.
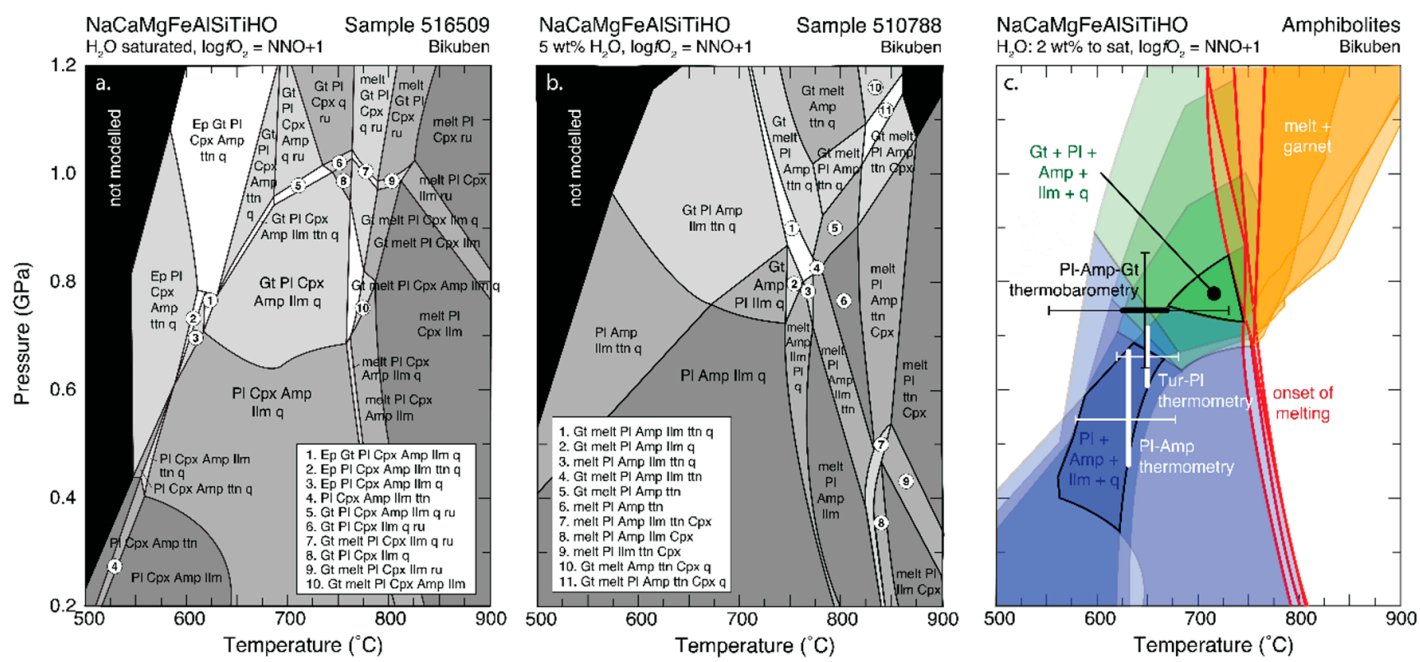

Figure 6. Pseudosection results for Bikuben assemblages; $(\mathbf{a}, \mathbf{b})$ Typical pseudosections for a Bikuben calc-silicate and amphibolite, respectively; (c) Compilation of Bikuben pseudosection results showing fields and reactions observed in these samples. Tourmaline-plagioclase and plagioclase-amphibole thermometry results agree well with the field for pl-amp-ilm-q peak parageneses in meta-basalts, and fields for garnet-bearing assemblages in meta-basalts and calc-silicates also agree well and provide a narrow field in $\mathrm{P}-\mathrm{T}$ consistent with plagioclase-amphibole-garnet-clinopyroxene thermobarometry. The onset of melting and the field of coexisting garnet and melt are also shown. Minerals starting with a capital letter were modelled as a solid solution. Mineral abbreviations as in Figure 3 and $\mathrm{cpx}=$ clinopyroxene. 


\subsubsection{Anatexis}

Partial melting is calculated to commence between approximately 725 and $775{ }^{\circ} \mathrm{C}$ for typical amphibolite and calc-silicate bulk compositions of Bikuben (Figure 6, the bulk composition for the actual migmatite samples is unavailable). This temperature is close to the maximum temperature of the amphibolites of Bikuben, but still suggests a steep thermal gradient in this fragment. The presence of leucosomes on garnet (Figure 21), and the irregular rims of garnet in contact with partial melt suggest that garnet is being resorbed by the melt. This peritectic reaction takes place in the orange field in Figure 6c, with the garnet mode progressively decreasing as temperature increases and/or pressure decreases.

\subsubsection{Ultramafic Rocks}

The ultramafic rocks of the Tartoq belt are dominated by antigorite and spinel. Relicts of tremolite, anthophyllite, and olivine are present, and pseudomorphs of antigorite + brucite after olivine are common. Spinel grains are mostly magnetite with a Cr-spinel core. The pseudosections (Figure 7) position the appearance of olivine at between 500 and $580{ }^{\circ} \mathrm{C}$ depending on bulk composition and pressure, preceded by tremolite at 350 to $450{ }^{\circ} \mathrm{C}$. The mode of tremolite strongly depends on the Ca content of the ultramafic rock. Anthophyllite comes in at 550 to $600{ }^{\circ} \mathrm{C}$. Locally, domains of tremolite + anthophyllite + spinel are observed in thin sections with antigorite present only as a retrograde replacement along fractures, suggesting the occurrence of a paragenesis without antigorite. The antigorite-out isograd is encountered at $650{ }^{\circ} \mathrm{C}$ for the $7 \mathrm{kbar}$ pressure constrained from the enclosing amphibolites (see Figure 6). Moreover, anthophyllite veins were observed in an ultramafic body in Nuna Qaqortoq. This suggests that the antigorite-out isograd has indeed locally been reached. The extensive retrograde overprinting of the ultramafics complicates assessment of their peak metamorphic conditions, but their relic mineralogy suggests conditions in excess of $600{ }^{\circ} \mathrm{C}$. Pressure cannot be constrained from the parageneses.

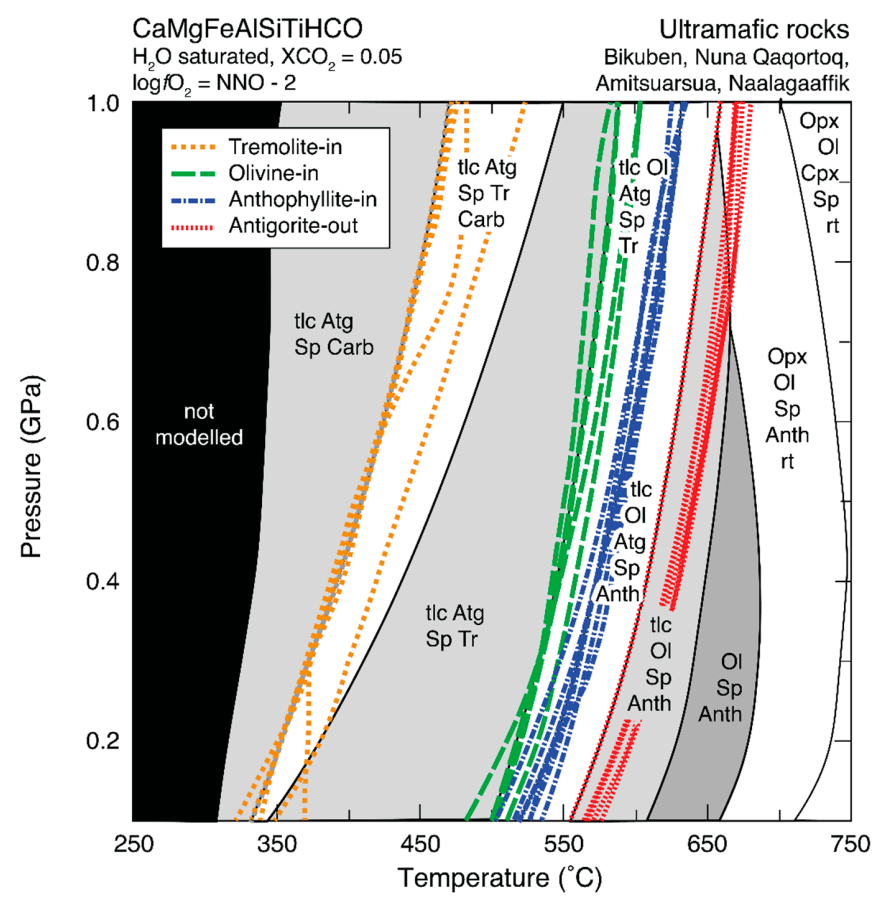

Figure 7. Typical pseudosection for an ultramafic rock with the locations for the tremolite-in, olivine-in, anthophyllite-in and antigorite-out reactions shown for the full range of ultramafic rock compositions throughout the Tartoq belt. Minerals starting with a capital letter were modelled as a solid solution. Atg = antigorite; $\mathrm{tlc}=$ talc; $\mathrm{sp}=$ spinel; $\mathrm{carb}=$ carbonate; $\mathrm{tr}=$ tremolite; $\mathrm{ol}=$ olivine; anth = anthophyllite; opx = orthopyroxene; $r t=$ rutile; $\mathrm{cpx}=$ clinopyroxene. 
Retrogression is extensive in the ultramafics, and we interpret all of the brucite to represent breakdown of olivine in the reaction olivine + fluid $=$ brucite + antigorite, given that the bulk compositions are too silicic to permit for primary brucite. This reaction constrains the retrograde conditions to below $400{ }^{\circ} \mathrm{C}$. The rims of the ultramafic bodies are converted into talc-magnetite-ankerite schists during this retrogression, which indicates introduction of $\mathrm{CO}_{2}$.

\section{Metamorphic History of the Tartoq Belt}

\subsection{Peak Metamorphism}

Peak metamorphic conditions in the Tartoq belt vary from upper greenschist to granulite facies conditions (ca. 450 to $750^{\circ} \mathrm{C}$ at 2 to $7.5 \mathrm{kbar}$, Figure 8 ). The majority of the belt records amphibolite facies conditions, with greenschist localities limited to Nuuluk and southern Iterlak, and granulite-facies migmatites restricted to Bikuben. The spatial distribution of metamorphic grades is not systematic, although there is a broad increase in grade from west to east. More significantly, higher grades are found for thrust sheets that contain meta-gabbros and ultramafics, such as those in eastern Iterlak, Bikuben, and central Naalagaaffik (e.g., Figure 5c). In Iterlak, there is a distinct step in metamorphic grade across the main thrust from lower to upper amphibolite facies, and a similar bimodality is present for the centre of Naalagaaffik compared to outcrops on either side. This suggests that gabbro and ultramafic-rich thrust sheets represent deeper crustal levels, in agreement with the interpretation of the ultramafic bodies as lower crustal cumulates [8].

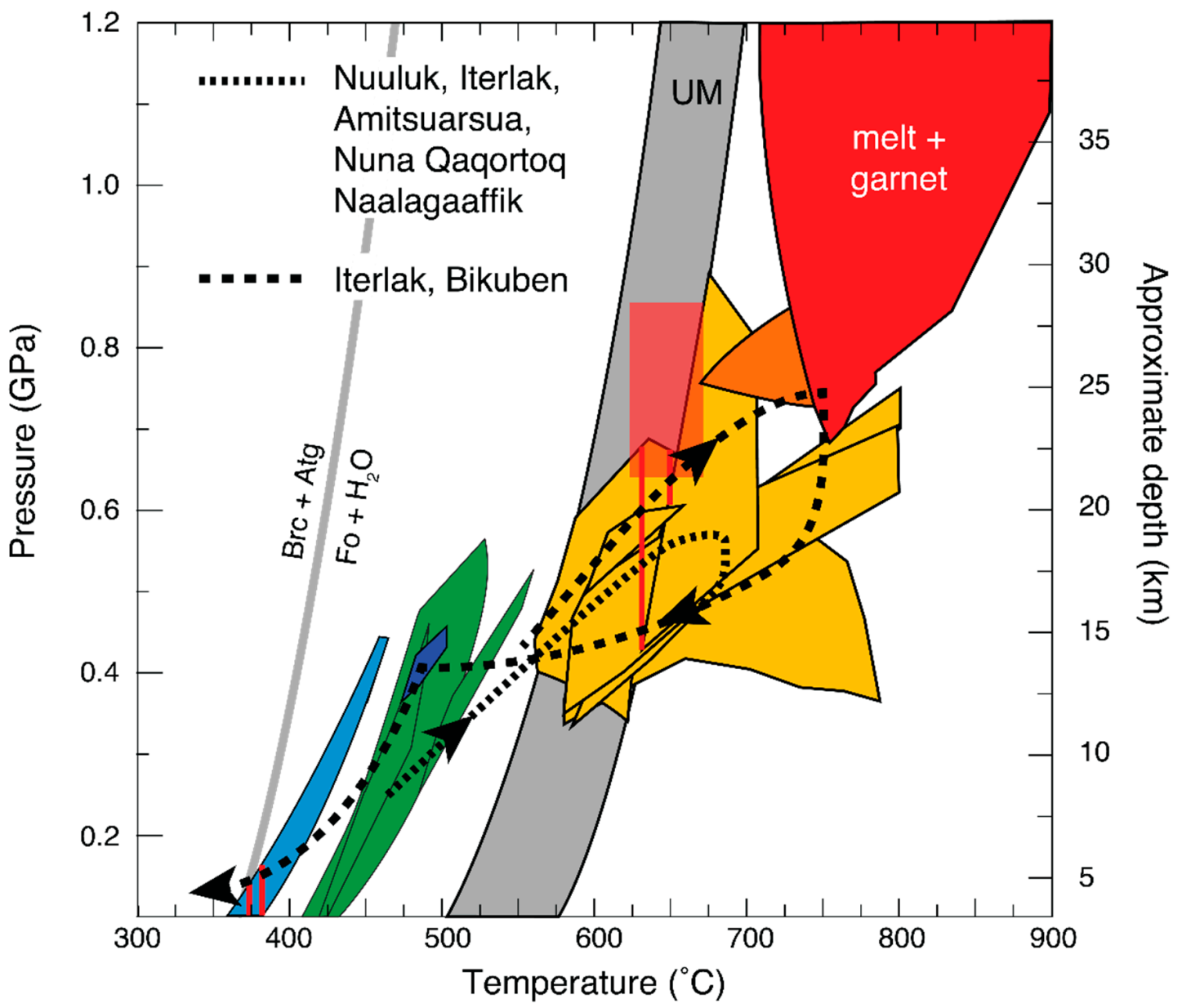

Figure 8. Compilation of all pseudosection and thermobarometry (in red) P-T constraints and the proposed metamorphic $\mathrm{P}-\mathrm{T}$ paths derived from these. Prograde greenschists in green, amphibolites in yellow, granulite in orange, migmatites in red, ultramafic rocks in grey, retrograde assemblages in blue. 


\subsection{Retrogression}

There are two distinct retrogression stages. The first is characterized by a mineral paragenesis of actinolite + epidote + plagioclase + titanite + quartz \pm carbonate \pm chlorite in meta-basalts and calc-silicates. It is ubiquitous throughout the belt and is remarkably consistent in mineral textures and compositions. The retrograde assemblage forms in the reaction hornblende + plagioclase + ilmenite $=$ actinolite + epidote + albite $\left(\mathrm{An}_{<5}\right)+$ titanite. Where garnet is present, it is replaced by epidote. Metamorphic conditions for this stage are narrowly constrained from overlapping pseudosection fields to the lower amphibolite facies at 475 to $500{ }^{\circ} \mathrm{C}$ and $4 \mathrm{kbar}$ (Figures $4 \mathrm{~d}$ and 8). The ubiquitous occurrence of this paragenesis suggests re-equilibration of the entire belt at these conditions. This is interpreted to represent the emplacement of the various fragments of the belt in their current configuration and their imbrication with the TTG gneisses (see also [1]).

The second stage of retrogression is associated with the extensive carbonation of the belt, local sulfidization, and formation of the gold mineralizations in shear zones. Metamorphic conditions are lower greenschist-facies with tourmaline thermometry constraining the temperature to $380 \pm 50{ }^{\circ} \mathrm{C}$, in agreement with the $350-450{ }^{\circ} \mathrm{C}$ calculated from arsenopyrite thermometry by Evans and King [9]. The relevant pseudosection field intersects the tourmaline thermometry values at a pressure of $<1 \mathrm{kbar}$ (Figure 8), as does the forsterite $+\mathrm{H}_{2} \mathrm{O}$ to brucite + antigorite reaction observed in the ultramafic rocks. This indicates that the hydrothermal activity took place at a depth of less than $3 \mathrm{~km}$. The presence of graphite and sulfides further suggests that it took place under reducing conditions.

\section{Synthesis and Implications}

The Tartoq belt of southwest Greenland represents a metamorphosed oceanic crust section of Archaean age. Lithologies range from gabbroic intrusives and ultramafic cumulate bodies, to meta-basaltic sills, dykes and flows, to calc-silicates and minor non-magmatic sediments including banded iron formations. Metamorphism of these rocks took place in a tectonically active environment with development of a penetrative foliation, gneissic banding, isoclinal folding, and partial transposition of units.

Conditions range from upper-greenschist to lower-granulite facies conditions with development of anatexis at the highest-grade conditions around $750{ }^{\circ} \mathrm{C}$ at $7.5 \mathrm{kbar}$. The low K-content of Tartoq lithologies, and the presence of restitic garnet in the anatectic gneisses results in these partial melts having a TTG-type major element composition. Combining the mineral and melt modes from the pseudosections with mineral-melt trace element partition coefficients for tonalites [36] allows for the trace element signature of the partial melts to be estimated (Figure 9, Supplementary Table S4). The melts show enrichment in incompatible elements and the light over heavy Rare Earth Element (REE) ratio compared to their parent amphibolite. There is reasonable agreement between the mid-ocean ridge basalt (MORB) normalized estimated melt composition and the measured bulk compositions of TTG gneisses enclosing the Tartoq belt (Figure 9). However, the melt REE pattern is at the low end of the range observed in the TTG gneisses, which reflects the low mode of garnet in the restite. The peritectic breakdown of garnet into the melt as observed in Bikuben, and modelled to take place in the pseudosection as the melt fraction increases, will further reduce this signature. We therefore conclude that the TTG gneisses that enclose the Tartoq belt may have formed from partial melting of mafic greenstone belt lithologies, but this must have taken place at higher pressures where garnet is a more abundant restite phase.

Peak metamorphism was followed by the return flow of greenstone fragments during which the Tartoq belt supracrustals were imbricated with the enclosing TTG gneisses. This imbrication is associated with felsic mylonite thrust sheets of proposed TTG protolith, and the development of a ubiquitous actinolite-albite-titanite-epidote-quartz \pm chlorite overprinting mineral paragenesis. This indicates that the imbrication of the Tartoq belt took place at conditions around $500{ }^{\circ} \mathrm{C}$ and $12 \mathrm{~km}$ depth. The ultramafic bodies are extensively retrogressed to antigorite + magnetite in this event with a rim of talc-magnetite-ankerite schists. Dating of the felsic mylonite sheets [7] provides a 
maximum age of $3 \mathrm{Ga}$ for this imbrication. Given the maximum age of $3.2 \mathrm{Ga}$ for mantle extraction of the mafic Tartoq lithologies [6], this provides a $<200$ Myr window for crust formation to burial and peak metamorphism, to uplift and imbrication.

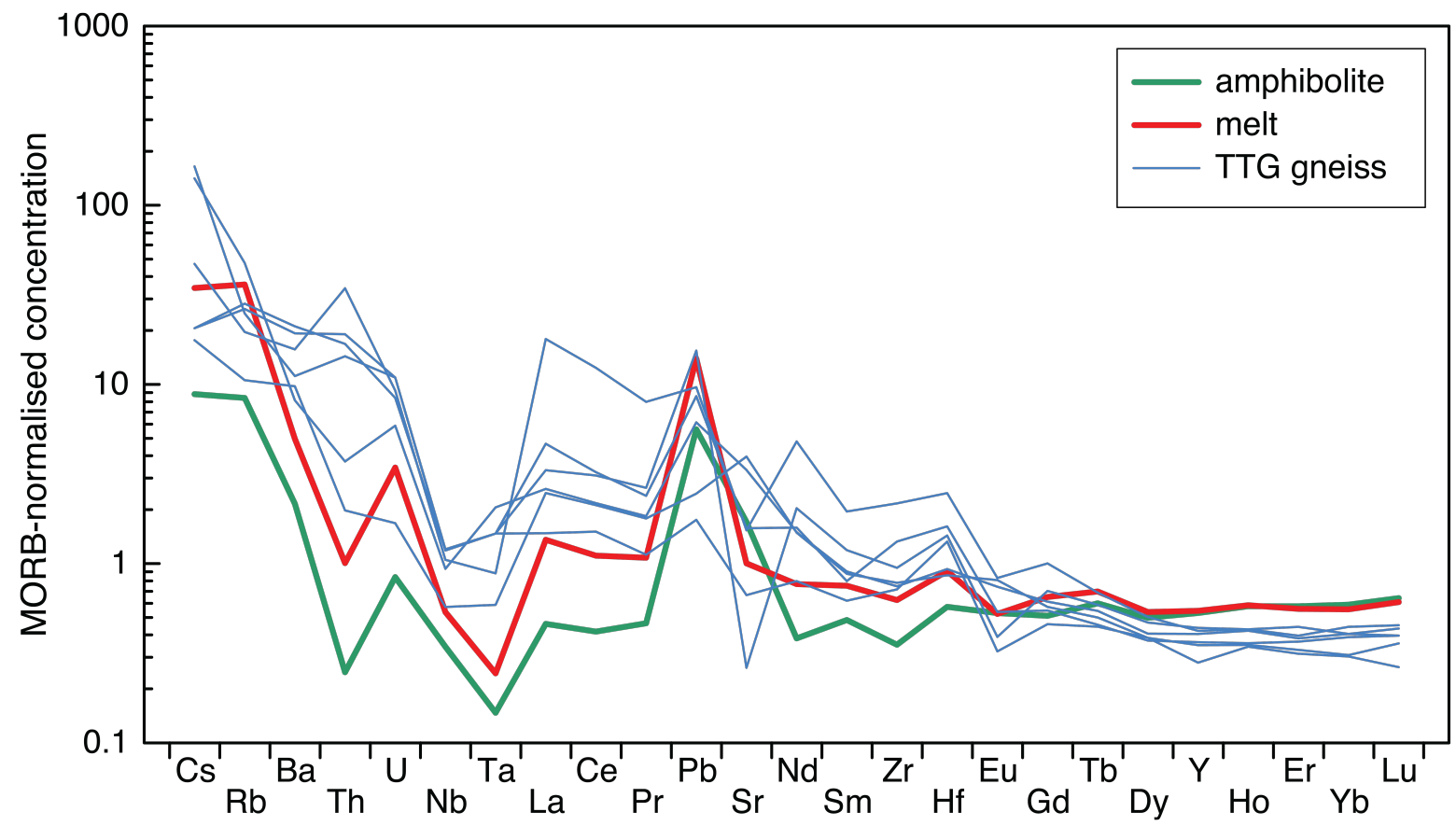

Figure 9. Comparison between the calculated trace element pattern of the partial melt (in red) and that of TTG gneisses that enclose the Tartoq greenstone belt (in blue). The composition of the parent amphibolite is also shown (sample 516509, in green). The trace element pattern of the partial melt is calculated from the pseudosection mineral and melt modes at $750{ }^{\circ} \mathrm{C}$ and $8 \mathrm{kbar}$ and the mineral-melt partition coefficients for tonalite from [34]. This calculation uses the solution models from [35].

A second intense and pervasive but shear zone-localized retrogression overprints the mafic rocks to a chlorite-albite-epidote-titanite-calcite greenschist assemblage and leads to appearance of brucite after olivine in the ultramafics. This retrogression is linked to introduction of hydrothermal fluids and leads to quartz-ankerite veins with gold mineralization. Fuchsite, pyrite, rutile, and tourmaline are also associated with this hydrothermal retrogression. Conditions are estimated at $380 \pm 50^{\circ} \mathrm{C}$ at a pressure below 1 kbar.

The textures and kinematics observed in the Tartoq greenstone belt indicate that it was part of a convergent margin [1]. In particular, the co-axial burial and exhumation history is consistent with a subduction zone geotectonic setting where initial subduction and burial of rocks is followed by detachment, return flow and exhumation. However, the Tartoq P-T history defines a prograde path that is markedly shallower than in modern-day subduction environments (cf., [36]), in agreement with models for subduction in the Archaean under conditions of a hotter mantle and more buoyant oceanic crust (e.g., [37]). As a result, the downgoing slab is comparatively hot and extends into the granulite-facies partial melting field, rather than follow a trajectory towards the eclogite-facies. This has important implications, because it results in a geodynamically weak and relatively buoyant slab that is unable to sink into the mantle to generate a significant 'slab pull' or to transfer this force to the up-dip oceanic crust. We therefore conclude that subduction could not be sustained, and instead advocate that the $\mathrm{P}-\mathrm{T}-\sigma$ history of the Tartoq greenstone belt demonstrates a convergence process where segments of oceanic crust are stacked together by repeated aborted subduction. This indicates that horizontal tectonics was operating at $>3 \mathrm{Ga}$, but that slab pull was not a driving force, consistent with previous field and modelling results $[1,37]$. 
Supplementary Materials: The following are available online at http:/ / www.mdpi.com/2076-3263/8/10/367/ s1, Table S1: Bulk rock compositions for samples used in pseudosection modeling; Table S2: Major element compositions for minerals in the Tartoq greenstone belt; Table S3: Geothermobarometry results; Table S4: Bulk rock compositions for TTG gneisses and the calculated partial melt composition.

Author Contributions: Conceptualization, V.v.H.; Methodology, V.v.H., C.C., and S.R.; Fieldwork, V.v.H., K.S., and A.K., Writing-Original Draft Preparation, V.v.H., C.C., and S.R.; Writing-Review \& Editing, all authors.

Funding: The fieldwork at the basis of this research was largely funded by the Greenland Bureau of Minerals and Petroleum and the Geological Survey of Denmark and Greenland (GEUS). V.v.H. acknowledges financial support through an Osisko research stipend.

Acknowledgments: We thank Brian Windley, Ali Polat, Dennis Schlatter, Annika Dziggel, and Kirsty Reynolds for their contributions during fieldwork and discussions on the Tartoq belt rocks. Logistic support for fieldwork was provided by the Greenland Bureau of Minerals and Petroleum and the Geological Survey of Denmark and Greenland (GEUS) and is gratefully acknowledged.

Conflicts of Interest: The authors declare no conflict of interest. The funders had no role in the design of the study; in the collection, analyses, or interpretation of data; in the writing of the manuscript, or in the decision to publish the results.

\section{References}

1. Kisters, A.F.M.; van Hinsberg, V.J.; Szilas, K. Geology of an Archaean accretionary complex-The structural record of burial and return flow in the Tartoq Group of South West Greenland. Precambrian Res. 2012, 220-221, 107-122. [CrossRef]

2. Van Hinsberg, V.J.; Szilas, K.; Kisters, A.F.M. The Tartoq Group, SW Greenland: Mineralogy, Textures and a Preliminary Metamorphic to Hydrothermal History; GEUS, Geological Survey of Denmark and Greenland: Copenhagen, Denmark, 2010; pp. 1-43.

3. Windley, B.F.; Garde, A.A. Arc-generated blocks with crustal sections in the North Atlantic craton of West Greenland: Crustal growth in the Archean with modern analogues. Earth-Sci. Rev. 2009, 93, 1-30. [CrossRef]

4. Higgins, A.K.; Bondesen, E. Supracrustals of pre-Ketilidian age (the Tartoq Group) and their relationships with Ketilidian supracrustals in the Ivigtut region, South-West Greenland. Grønl. Geol. Unders. Rapp. 1966, $18,1-20$.

5. Nutman, A.P.; Kalsbeek, F. A minimum age of $2944 \pm 7$ Ma for the Tartoq Group, South-West Greenland. Grønl. Geol. Unders. Rapp. 1994, 161, 35-38.

6. Szilas, K.; van Hinsberg, V.J.; Kisters, A.F.M.; Hoffmann, J.E.; Windley, B.F.; Kokfelt, T.F.; Schersten, A.; Frei, R.; Rosing, M.T.; Muenker, C. Remnants of arc-related Mesoarchaean oceanic crust in the Tartoq Group of SW Greenland. Gondwana Res. 2013, 23, 436-451. [CrossRef]

7. Polat, A.; Kokfelt, T.; Burke, K.C.; Kusky, T.M.; Bradley, D.C.; Dziggel, A.; Kolb, J. Lithological, structural, and geochemical characteristics of the Mesoarchean Târtoq Greenstone Belt, Southern West Greenland, and the Chugach-Prince William Accretionary Complex, Southern Alaska: Evidence for uniformitarian plate-tectonic processes. Can. J. Earth Sci. 2016, 53, 1336-1371. [CrossRef]

8. Szilas, K.; van Hinsberg, V.J.; Creaser, R.A.; Kisters, A.F.M. The geochemical composition of serpentinites in the Mesoarchaean Tartoq Group, SW Greenland: Harzburgitic cumulates or melt-modified mantle? Lithos 2014, 198-199, 103-116. [CrossRef]

9. Evans, D.M.; King, A.R. Sediment and shear-hosted gold mineralization of the Tartoq Group supracrustals, southwest Greenland. Precambrian Res. 1993, 62, 61-82. [CrossRef]

10. Petersen, J.S. Gold Mineralization in the Taartoq Group Greenstones, SW Greenland; NunaOil A/S: Nuuk, Greenland, 1991; pp. 1-75.

11. Szilas, K.; van Hinsberg, V.J.; Kisters, A.F.M.; Kokfelt, T.F.; Schersten, A.; Windley, B.F. Remnants of Mesoarchaean oceanic crust in the Tartoq Group, South-West Greenland. Geol. Surv. Den. Greenl. Bull. 2011, 23, 57-60.

12. Leake, B.E.; Woolley, A.R.; Birch, W.D.; Burke, E.A.J.; Ferraris, G.; Grice, J.D.; Hawthorne, F.C.; Kisch, H.J.; Krivovichev, V.G.; Schumacher, J.C.; et al. Nomenclature of amphiboles: Additions and revisions to the International Mineralogical Association's amphibole nomenclature. Eur. J. Miner. 2004, 16, 191-196. [CrossRef] 
13. Connolly, J.A.D.; Petrini, K. An automated strategy for calculation of phase diagram sections and retrieval of rock properties as a function of physical conditions. J. Metamorph. Geol. 2002, 20, 697-708. [CrossRef]

14. Connolly, J.A.D. Computation of phase equilibria by linear programming: A tool for geodynamic modeling and its application to subduction zone decarbonation. Earth Planet. Sci. Lett. 2005, 236, 524-541. [CrossRef]

15. Holland, T.J.B.; Powell, R. An improved and extended internally consistent thermodynamic dataset for phases of petrological interest, involving a new equation of state for solids. J. Metamorph. Geol. 2011, 29, 333-383. [CrossRef]

16. White, R.W.; Powell, R.; Holland, T.J.B.; Johnson, T.E.; Green, E.C.R. New mineral activity-composition relations for thermodynamic calculations in metapelitic systems. J. Metamorph. Geol. 2014, 32, 261-286. [CrossRef]

17. Newton, R.C.; Wood, B.J.; Kleppa, O.J. Thermochemistry of silicate solid-solutions. Bull. Miner. 1981, 104, 162-171.

18. Diener, J.F.A.; Powell, R. Revised activity-composition models for clinopyroxene and amphibole. J. Metamorph. Geol. 2012, 30, 131-142. [CrossRef]

19. White, R.W.; Powell, R.; Clarke, G.L. The interpretation of reaction textures in Fe-rich metapelitic granulites of the Musgrave Block, Central Australia: Constraints from mineral equilibria calculations in the system. J. Metamorph. Geol. 2002, 20, 41-55. [CrossRef]

20. Padron-Navarta, J.A.; Lopez Sanchez-Vizcaino, V.; Hermann, J.; Connolly, J.A.D.; Garrido, C.J.; Teresa Gomez-Pugnaire, M.; Marchesi, C. Tschermak's substitution in antigorite and consequences for phase relations and water liberation in high-grade serpentinites. Lithos 2013, 178, 186-196. [CrossRef]

21. Higgins, A.K. The Tartoq Group on Nuna Qaqertoq and in the Iterdlak Area, South-West Greenland. Grønl. Geol. Unders. Rapp. 1968, 17, 1-17.

22. Petersen, J.S. Nuuluk-Iterlak Gold and Massive Sulfide Project, Taartoq Archaean Greenstone Belt, SW Greenland; NunaOil A/S: Nuuk, Greenland, 1992; pp. 1-164.

23. Gutzmer, J. Ancient sub-seafloor alteration of basaltic andesites of the Ongeluk Formation, South Africa: Implications for the chemistry of Paleoproterozoic seawater. Chem. Geol. 2003, 201, 37-53. [CrossRef]

24. De Wit, M.J.; Furnes, H. 3.5-Ga hydrothermal fields and diamictites in the Barberton Greenstone Belt-Paleoarchean crust in cold environments. Sci. Adv. 2016, 2, e1500368. [CrossRef] [PubMed]

25. Appel, P.W.U.; Secher, K. On a gold mineralization in the Precambrian Tartoq Group, SW Greenland. J. Geol. Soc. Lond. 1984, 141, 273-278. [CrossRef]

26. Holland, T.; Blundy, J. Non-ideal interactions in calcic amphiboles and their bearing on amphibole-plagioclase thermometry. Contrib. Miner. Petrol. 1994, 116, 433-447. [CrossRef]

27. Anderson, J.L.; Smith, D.R. The effect of temperature and oxygen fugacity on Al-in-hornblende barometry. Am. Miner. 1995, 80, 549-559. [CrossRef]

28. Kohn, M.J.; Spear, F.S. Two new geobarometers for garnet amphibolites, with applications to southeastern Vermont. Am. Miner. 1990, 75, 89-96.

29. Graham, C.M.; Powell, R. A garnet-hornblende geothermometer: Calibration, testing, and application to the Pelona Schist, Southern California. J. Metamorph. Geol. 1984, 2, 13-31. [CrossRef]

30. Ravna, E.K. The garnet-clinopyroxene $\mathrm{Fe}^{2+}-\mathrm{Mg}$ geothermometer: An updated calibration. J. Metamorph. Geol. 2000, 18, 211-219. [CrossRef]

31. Van Hinsberg, V.J.; Schumacher, J.C. The geothermobarometric potential of tourmaline, based on experimental and natural data. Am. Miner. 2009, 94, 761-770. [CrossRef]

32. Van Hinsberg, V.J.; Schumacher, J.C. Intersector element partitioning in tourmaline: A potentially powerful single crystal thermometer. Contrib. Miner. Petrol. 2007, 153, 289-301. [CrossRef]

33. Lanari, P.; Engi, M. Local bulk composition effects on metamorphic mineral assemblages. Rev. Miner. Geochem. 2017, 83, 55-102. [CrossRef]

34. Andersen, D.J.; Lindsley, D.H. New (and final!) models for the Ti-magnetite/ilmenite geothermometer and oxygen barometer. In Abstracts of American Geophysical Union 1985 Spring Meeting; American Geophysical Union: Washington, DC, USA, 1985; Volume 66, p. 416.

35. Green, E.C.R.; White, R.W.; Diener, J.F.A.; Powell, R.; Holland, T.J.B.; Palin, R.M. Activity-composition relations for the calculation of partial melting equilibria in metabasic rocks. J. Metamorph. Geol. 2016, 34, 845-869. [CrossRef] 
36. Bédard, J.H. A catalytic delamination-driven model for coupled genesis of Archaean crust and sub-continental lithospheric mantle. Geochim. Cosmochim. Acta 2006, 70, 1188-1214. [CrossRef]

37. Moyen, J.F.; van Hunen, J. Short-term episodicity of Archaean plate tectonics. Geology 2012, 40, 451-454. [CrossRef]

(c)

(C) 2018 by the authors. Licensee MDPI, Basel, Switzerland. This article is an open access article distributed under the terms and conditions of the Creative Commons Attribution (CC BY) license (http:// creativecommons.org/licenses/by/4.0/). 